\title{
Phosphorus mass balance and input load estimation from the wet and dry periods in tropical semiarid reservoirs
}

\section{Maria de Jesus Delmiro Rocha}

Federal University of Ceara: Universidade Federal do Ceara

Iran Eduardo Lima Neto ( $\nabla$ iran@deha.ufc.br)

Federal University of Ceara: Universidade Federal do Ceara https://orcid.org/0000-0001-8612-5848

\section{Research Article}

Keywords: total phosphorus, phosphorus dynamics, internal and external loads, eutrophication, water quality modeling.

Posted Date: April 6th, 2021

DOl: https://doi.org/10.21203/rs.3.rs-352835/v1

License: (c) (i) This work is licensed under a Creative Commons Attribution 4.0 International License.

Read Full License 


\title{
Phosphorus mass balance and input load estimation from the wet and dry periods in
}

\section{tropical semiarid reservoirs}

\author{
Maria de Jesus Delmiro Rocha ${ }^{a}$; Iran Eduardo Lima Neto ${ }^{\text {** }}$ \\ ${ }^{a}$ Department of Hydraulic and Environmental Engineering, Federal University of Ceará - UFC, B1. 713, Center of \\ Technology, Fortaleza, Ceará, Brazil. \\ * Corresponding author \\ E-mail address: iran@deha.ufc.br
}

\begin{abstract}
The dynamics of total phosphorus (TP) in 18 strategic reservoirs of the high-density reservoir network of the Brazilian semiarid was evaluated during the wet and dry periods for the past 12 years. Seasonal TP concentrations presented no significant differences for about $90 \%$ of the reservoirs $(\mathrm{p}>0.05)$. This was attributed to a trade-off between the hydrological/limnological processes occurring in the two seasons. Then, a transient complete-mix mass balance model was applied with particular adaptations for the tropical semiarid reservoirs to estimate the TP load for each season. Because of the relatively well mixed conditions and high hypolimnetic dissolved oxygen concentrations during the wet season, the wet load was assumed to represent the external TP load. On the other hand, because of the absence of reservoir inflow during the dry season, phosphorus release under anoxic sediment conditions and wind-induced resuspension under shallow water conditions, the dry load was assumed to reflect the internal TP load. The maximum external loads were related to peak inflows, notably after drought periods. Consistently, the largest internal loads were obtained during the drought periods, when the reservoirs were shallower and more prone to phosphorus release and resuspension. By comparing the impact of the two input load types, the wet period load was predominant in $72 \%$ of the reservoirs. The areal phosphorus loads ranged from 0.66 to $7.29 \mathrm{gP} . \mathrm{m}^{2} . \mathrm{yr}^{-1}$, which were consistent with the literature, despite the very high density of reservoirs. Finally, power-law curves including data for all studied reservoirs were adjusted between the dry period load and volume, dry and wet period loads, wet period load and inflow, and total load and catchment area, resulting in satisfactory $R^{2}(0.66-0.82)$.
\end{abstract}

Keywords: total phosphorus; phosphorus dynamics; internal and external loads; eutrophication; water quality modeling. 


\section{Introduction}

The reduction of phosphorus loading has been the major effort to deal with the eutrophication issue (Lepori and Roberts 2017). The risk of eutrophication in an aquatic ecosystem depends partly on nutrient inputs, especially phosphorus (P). This nutrient is critical with regards to primary productivity (Le Moal et al. 2019). Total $\mathrm{P}$ in waters consists of a variety of inorganic and organic forms (Doan et al. 2018) and the processes within the lake are also an important source of contribution (Nürnberg 2009). Additionally, lake's morphometry, climatic conditions, oxygen concentration and macrophyte presence play an important role on P dynamics (KowalczewskaMadura et al. 2019; Seitz et al. 2020; Mesquita et al. 2020; Wiegand et al. 2021), especially on its spatial and temporal variability (North et al. 2015).

A broader distinction with regard to phosphorus origins is widely accepted: phosphorus carried with water through rivers to downstream lakes or reservoirs is called external P loading (Song et al. 2017). The external sources may be further divided into point and non-point sources (Bowes et al. 2008). In contrast, P released from sediments within the waterbody is known as internal loading (Nikolai and Dzialowski 2014). P enriched sediments are a result of a long-term accumulation process from $\mathrm{P}$ entering the lake. Then, at some extent, there is a relation between these two sources once external ones origin internal nutrient recycling. Phosphorus resuspension due to the effect of wind shear in shallow lakes is also a potential source of internal loading (Søndergaard et al. 2003; Araújo et al. 2019). The formidable challenge, though, is tracking lake water P and distinguish its origin from internal or external load (Nürnberg et al. 2013).

Commonly, external P load represents a higher percentage in an annual P budget and its relevance have formed the basis for classic predictive models such as the P model of Vollenweider (1968) (Lepori and Roberts 2017). The majority of P that comes to a lake ecosystem, however, is usually stored in the bottom sediment (Kiani et al. 2020), which in appropriate conditions return to the water column (Moura et al. 2020). P releasing from sediments, the internal loading, results from physical and/or biogeochemical mechanisms that operate on different temporal and spatial scales in a complex process (Orihel et al. 2017). Additionally, it might pose a high risk of becoming an additional $\mathrm{P}$ source and contribute to the total in-lake $\mathrm{P}$ bioavailability. This process has a high potential to significantly deteriorate the trophic state and water quality, mainly in eutrophic or hypereutrophic environments (Doan et al. 2018)

Then, the TP dynamics is strongly influenced by the equilibrium of P between the water column and the sediment (Song et al. 2017). Turnover events such as blooms or increased turbidity during summer might be indicators of internal load in polymictic lakes (Nürnberg 2009). All of the aforementioned aspects highlight the 
importance of internal loading to lake modeling. However, its quantification and/or comparison to external $\mathrm{P}$ loading is seldom performed.

While the external load is normally evaluated from the product of flow rate by concentration measured or modeled at the lake entrance (Bowes et al. 2008), there are various ways to determine the internal load, depending on data availability (Nürnberg et al. 2012). Some approaches to internal load quantification may be: determination from hypolimnetic $\mathrm{P}$ increases, regression analysis, time-dynamic modeling, estimates from anoxic active area and mass balance approaches (Nürnberg 2009). To polymictic lakes the application of the mass balance approach is readily recommended as long as mass changes and fluxes are measured (Doan et al. 2018).

Pioneer studies on TP modelling in lakes and reservoirs started with Vollenweider (1968). A massbalance model applied to well mixed lakes to provide transient analysis from measured TP concentration was proposed. Furthermore, applications and improvements were performed in recent studies to assess the model's predictive ability (Chapra and Dolan 2012; Molina-Navarro et al. 2014; Shimoda and Arhonditsis 2015; Chapra et al. 2016; Katsev, 2017; Araújo et al. 2019; Lira et al. 2020). The P budget from measured concentration, however, has the potential of not separating different sources, mainly the internal sources such as sediment release, bioturbation, and resuspension (Nürnberg et al. 2012). As a workaround, a mass balance analysis in a controlled period when the inflow is nill may allow the quantification of the internal load as the main TP load input.

Additionally, although the simplicity, the complete-mix hypothesis can be taken into consideration based on the trade-off: model complexity vs. data availability. Besides, for the Brazilian semiarid reservoirs, the occurrence of a diurnal mixing cycle is a particular characteristic (Lira et al. 2020; Mesquita et al. 2020). For regions with lack of measured TP data, then, the application of this parsimonious model stands out as a feasible, but still little applied, tool to estimate TP load contributions and search the distinguishing of its sources.

The influence of internal and external TP loads on the total P budget remains also poorly understood in regions such as the highly populated Brazilian semiarid, which has a very high-density reservoir network that has been built over the past century to overcome the negative water balance (Lima Neto et al. 2011; Campos et al. 2016). Nevertheless, most of these water supply reservoirs are already eutrophic or hypereutrophic, which makes the water quality issue a great concern for water resources management (Lopes et al. 2014; Pacheco and Lima Neto, 2017; Lacerda et al. 2018; Lira et al. 2020). Furthermore, the climatic/hydrologic conditions of this region are marked by a clear seasonality, with precipitation and reservoir inflows occurring basically in the first half of the year, while wind speed and evaporation rates are predominantly higher in the second half (Von Schiller et al. 2017; Chaves et al. 2019; Mesquita et al. 2020). On the other hand, differently from temperate regions, water 
temperature is relatively high (around $30^{\circ} \mathrm{C}$ ) with a very narrow variation (up to about $\pm 4^{\circ} \mathrm{C}$ ) throughout the year (Souza Filho et al. 2006; Lima Neto, 2019). Hence, an analysis focusing on these two distinct periods (wet and dry seasons) might contribute to the understanding of TP dynamics and the role of internal and external TP loads to reservoirs in tropical semiarid regions.

Thus, the objective of this work was to model, assess and discuss the TP loads to strategic water supply reservoirs in the Brazilian semiarid to better understand the influence of external and internal loads on phosphorus dynamics. Specifically, the goals were: (i) to evaluate the dynamics of seasonal and interannual TP concentrations under the influence of the wet and dry periods, (ii) to model and assess circumstantial evidences for the large likelihood of internal load, (iii) to compare these internal loads in the context of external loading, and (iv) to analyze and propose general correlations between TP loads and reservoir/catchment characteristics. The results from this study will improve the knowledge of the limnology of tropical semiarid reservoirs and the proposed models/correlations will be potential tools for integrated water management.

\section{Methodology}

\section{$\underline{\text { 2.1. Study area }}$}

The study area covers eighteen monitored water supply reservoirs in the State of Ceará, Brazil, presented in Fig. 1. Table 1 details their specific location and general characteristics. These reservoirs are scattered in the twelve hydrologic regions in which the State of Ceará is divided for water resources management. The combined area of their catchments represents $59.02 \%$ of the state's area and their volume a total accumulated capacity of $10.19 \mathrm{~km}^{3}$. The shallowest reservoir is Colina (12 m deep), while the deepest is Castanhão (71 m deep). On average, the reservoirs have a depth of $23.85 \mathrm{~m}$. These water bodies support the network that supplies water for human, industrial and agricultural uses.

Landuse in the catchments is dominated by managed grasslands with a spread anthropogenic presence in which a variety of animal husbandry is carried out, including fish farming in some reservoirs. Agricultural land with irrigated crop production can be found in Jaguaribe river basin, whilst dispersed rural population practices primarily subsistence agriculture and plant extraction. With regards to climate, the median precipitation in the study are is $720.71 \mathrm{~mm} . \mathrm{yr}^{-1}$, varying from $605.07 \mathrm{~mm} . \mathrm{yr}^{-1}$, in the Colina reservoir catchment, to $1378.62 \mathrm{~mm}^{\mathrm{yr}} \mathrm{r}^{-1}$ in the Itauna catchment. The rivers which supply these reservoirs are intermittent, with inflows occurring only during the rainy season (January to July). From 2012, almost the entire State of Ceará has faced a prolonged drought period that has lead to a continuous reduction in the reservoirs' volume due to low precipitation (Wiegand 
et al. 2020). A more detailed description of the geology, geomorphology and land use of the studied catchments can be found in CEARÁ (2020b).

Fig. 1 Location of the eighteen studied sites in the State of Ceará - Brazil, whose description is presented in

Table 1

Table 1 Physical characteristics of the studied reservoirs, their catchments and the period of available water quality data

\subsection{TP load estimation}

The TP load estimation was performed to identify and differentiate the roles of the wet and dry seasons in the input loading production. In the studied area, due to the particularity of the tropical semiarid climate, these two periods are clearly distinguishable. During the dry season, the flow in the rivers is completely interrupted, except for some rare perennialized segments. Excluding the coastal areas, the dry period extends to almost the entire second semester of the year. With regards to water quality, the data is usually measured four times a year, twice in each period, generally at the beginning and at the end of each one. Thus, in this study, the data collected from January to July were considered representing the wet season, while the data from August to December were considered as representative of the dry one.

Internal TP load production is expected to be stronger in the dry season, as dissolved oxygen concentration in the hypolimnion usually falls below $1.0 \mathrm{mg} / \mathrm{L}$ (Souza Filho et al. 2006), potentially causing P release from sediments (Moura et al. 2020), while, on the other hand, water volume is lower and wind speed is stronger, potentially causing wind-induced resuspension (Mesquita et al. 2020). Note that in larger reservoirs such as Castanhão (71 m deep), periods of low hypolimnetic dissolved oxygen (about $2 \mathrm{mg} / \mathrm{L}$ ) are also expected during the rainy season (Santos et al. 2017). This suggests that $\mathrm{P}$ release may also take place during the rainy period in such reservoirs. However, since in this period most of the total load is external due to high inflows, the internal load contribution to the budget during the rainy season is very small, consistently with Nürnberg et al. (2012).

Therefore, it was assumed that during the wet season (high inflows) prevails external loads, while the internal load is dominant during the dry season (absence of inflows). Meanwhile, aware of the possible existence of the internal load, even in small percentage of representation during the wet season, the possible external load contribution through non-point source, such as animal's access to the waterbody, during the dry season and also 
to avoid a generalization, the loads estimated in the rainy season will be referred as the wet period load and those estimated for the dry season as dry period load, while they intend to represent the external and internal loads, respectively. Additionally, it is important to highlight that, among a variety of methods for estimation of the internal P loading (Nürnberg 2009), the most suitable for this study considering the available data is a net estimate from complete P budgets (mass balance approach). By this method, the load is estimated by constructing a wholelake mass balance of $\mathrm{P}$, accounting for a global rate of sedimentation from the water column (Orihel et al. 2017).

\subsubsection{Total phosphorus model}

The transient complete-mix model presented in Equation (1) was designed to predict the average TP concentration in hypothetically well mixed lakes and reservoirs (Vollenweider 1968; Chapra 2008). The model involves parameters related with the lake morphometry, water balance and nutrient dynamics. It is noteworthy that this transient model is particularly suitable for semiarid regions due to the high seasonal and interannual variation of the morphometric parameters. The model was applied as a calibration process of $\mathrm{W}$ for time intervals of, at most, four months, in which the initial and final TP concentrations were available. The remaining parameters were calculated as an average over the period between these TP measurements. TP concentration, morphometric and water withdrawal data were provided by the Water Resources Management Company of the State of Ceará (COGERH), for the eighteen studied reservoirs (Ceará 2020a).

$T P(t)=T_{0} e^{-\left(\frac{Q}{V}+k\right) t}+\frac{W}{Q+k V}\left[1-e^{-\left(\frac{Q}{V}+k\right) t}\right]$

In which $\mathrm{TP}(\mathrm{t})$ : Total phosphorus concentration at a specific time $\left(\mathrm{kg} \cdot \mathrm{m}^{-3}\right) ; \mathrm{TP}_{\mathrm{o}}$ : Total phosphorus concentration at the initial time $\left(\mathrm{kg} \cdot \mathrm{m}^{-3}\right)$; t: Elapsed time (yr); V: Reservoir volume averaged over the elapsed time $\left(\mathrm{m}^{3}\right)$; W: TP load $\left(\mathrm{kg} . \mathrm{yr}^{-1}\right)$; Q: Released flow $\left(\mathrm{m}^{3} \cdot \mathrm{yr}^{-1}\right) ; \mathrm{k}$ : TP settling loss rate $\left(\mathrm{yr}^{-1}\right)$.

The application of Equation 1 consisted of taking paired measurements of $\mathrm{TP}$ concentration $\left[\mathrm{TP}_{\mathrm{o}}\right.$ and $\mathrm{TP}(\mathrm{t})$ ], the elapsed time between these measurements $(\mathrm{t})$ and the mean parameters of the reservoir for this time interval (V, Q and k) to estimate the average TP load. For the paired TP concentrations measured during the wet season, the fitted W refers to the load of the wet period. Similarly, from TP concentrations measured during the dry season, fitted $\mathrm{W}$ refers to the load of the dry period. The results, then, were converted to a monthly average. The areal phosphorus load was also obtained from the division of each estimated load by the mean lake surface 
area of the same time interval. The surface area was obtained through level-area-volume curves provided by CEARÁ (2020a).

The separation between wet and dry period was performed as previously detailed. This process was applied to all years of available data presented in Table 1. As a complete mixing hypothesis was assumed, average TP concentration at the reservoir outlet was applied in the calculations. Additionally, calculation of multiyear averages of TP load enhanced the reliability of the mass balance approach (see Nürnberg et al. 2012).

\subsubsection{Settling loss rate $(k)$ and retention time $(R T)$}

The general relevant processes of $\mathrm{P}$ removal dynamics from the water are algae consumption and physical sedimentation (Ansari and Gill 2014; Lira et al. 2020). The TP model applied in this study integrate these processes in the parameter (k), a global decay coefficient which accounts for the average P settling. The difficulty to obtain $\mathrm{k}$ experimentally or in a direct way, however, was outlined by its estimation through an empirical relationship that correlates $\mathrm{k}$ with the theoretical hydraulic residence time (RT). Hence, Equation 2 was adjusted and validated by Toné and Lima Neto (2020) for a wide range of Brazilian semiarid reservoirs. Additionally, it was also validated by Lima (2016) and Araújo et al. (2019) for reservoirs located specifically in the State of Ceará.

$\mathrm{k}=\frac{4}{\mathrm{RT}^{1 / 2}}$

It is noteworthy that similar empirical relations with $\mathrm{k}$ varying with the inverse of $\mathrm{RT}^{1 / 2}$ were also developed for temperate and tropical lakes by Vollenweider (1976) and Salas and Martino (1991), respectively, but with numerators of 1 and 2, respectively. However, this correlation with a numerator of 4 (Equation 2) intended to consider the effect of the higher water temperature of the Brazilian semiarid reservoirs $\left(\sim 30^{\circ} \mathrm{C}\right)$, as compared to those for temperate $\left(\sim 10^{\circ} \mathrm{C}\right)$ and tropical $\left(\sim 20^{\circ} \mathrm{C}\right)$ lakes. Higher water temperature leads to a combined effect of increasing $\mathrm{P}$ consumption by algae and decreasing water viscosity, then favoring higher phosphorus sedimentation rates (Toné and Lima Neto 2020). Note that a numerator of the order of 4 can also be obtained by applying the equations accounting for algae consumption and water viscosity (see Castagnino 1982) to convert the values of $\mathrm{k}$ from lakes with temperatures of about $10-20^{\circ} \mathrm{C}$ to lakes with temperatures of about $30^{\circ} \mathrm{C}$. Therefore, Eq. 2 is assumed to be reliable for the purposes of the present study.

The real residence time, quite more complex and depending on reservoir morphometry and hydrodynamics (Castellano et al. 2010), was replaced by the theoretical hydraulic residence time (RT). Considered 
a consistent assumption, it is in line with the complete-mix hydraulic behavior adopted here to model the reservoirs. Besides, simple approaches to obtain the water renewal time demonstrate to have good accuracy for relatively well-mixed lakes (Pilotti et al. 2014). Consistently, Brazilian semiarid reservoirs present weak stratification contrasts from top to bottom (up to about $1-5^{\circ} \mathrm{C}$ ), that are destroyed on a daily cycle (Lacerda et al. 2018; Lima Neto 2019; Mesquita et al. 2020).

The RT was calculated as presented in Equations 3 and 4 for the wet and dry periods, respectively. The common definition of residence time is given in Equation 3 (Vollenweider 1976; Salas and Martino 1991), which accounts for continuous river flows. However, due to the intermittent regime of the rivers and its complete dryness in the dry season, the replacement of the inflow (I) by the sum of the rates of released (Q) and evaporated (E) waters better fit the study area and was performed when modelling a time interval during the dry conditions.

$\mathrm{RT}=\frac{\mathrm{V}}{\mathrm{I}}$

$\mathrm{RT}=\frac{\mathrm{V}}{\mathrm{Q}+\mathrm{E}}$

In which RT: Theoretical hydraulic residence time; I: Inflow; Q: Released flow; E: Evaporated rate; and V: Reservoir's volume.

\subsubsection{Water quality and water balance data}

The studied reservoirs were selected based on the availability of measured TP concentration at the reservoir outlet, measured TP concentration in the water column and TP load (W) information. They integrate the total of 89 monitored reservoirs by COGERH where a continuous monitoring program is carried out. TP concentration measurements at the epilimnion consists in the most complete dataset available. Samples are collected about four times a year close to the reservoir dam or the floating pumping station, and then analyzed according to APHA (2005). The measurements in the hypolimnion, although less frequent and consequently representing a shorter dataset, were important to perform statistics analysis and evaluate the mixing hypothesis adopted, the proximity between epilimnion and hypolimnion concentrations, as well to support the use of TP concentration in the upper layers as a reference to estimate the input load.

With regards to TP load (W) data, COGERH has also elaborated an environmental inventory covering the catchment of each studied reservoir for the periods shown in Table 1. The methodology applied to elaborate these inventories was based on the Export Coefficient Modelling (ECM) approach (Johnes 1996), accounting for 
the main TP contributions sources and the total annual load to the reservoir. Due to the high cost and time demand to prepare these inventories, they were elaborated only once for the studied catchments. A detailed description of the methods of calculation of human activity intensity (livestock, crop, sewage, and others) and all considered catchment parameters is available in CEARÁ (2020b).

The volume (V) and depth (h) of each reservoir were characterized through daily water level measurements and level-volume curves provided by CEARÁ (2020a). The last three required parameters were reservoir inflow (I), evaporation (E), and released flow (Q). The monthly values of I and Q were also obtained from CEARÁ (2020a). These variables were estimated through a water balance equation, as described in Campos et al. (2016). It is important to highlight that, particularly for the inflow, once it is obtained from a water balance, it intends to account for the water coming from all sources to the water body. This implicates that the contributing base flow during the wet season and possible P-rich groundwater are incorporated in the model as external $\mathrm{P}$ sources, according to Orihel et al. (2017). Lastly, the evaporated height was quantified from the climatological normals of the closest climatological station to each reservoir (Brazil 2020).

\subsection{Comparison of different $P$ modeling approaches and model validation}

The validation of the estimated loads was performed through two approaches. Initially, a correlation analysis and evaluation of the coefficient of determination $\left(\mathrm{R}^{2}\right)$ was carried out between the mean modeled TP load and the reference load available by CEARÁ (2020b), estimated through the ECM method, for each reservoir. Moreover, as the Castanhão reservoir features two additional measured water quality and quantity datasets, the validation specifically of the wet TP load estimated for this reservoir was possible. An active fluviometric station is located in its main river allied with a monitoring point kept by COGERH, as shown in Fig. 1, in which riverine TP concentration is measured. The proximity between the fluviometric station and the water quality sampling point (less than 50 meters) and of those two with the reservoir (less than $24 \mathrm{~km}$ ) allow the estimation of the wet TP load from a flow-concentration approach (Bowes et al. 2008). This load was estimated through the multiplication of measured riverine TP concentration $\left(\mathrm{kg} \cdot \mathrm{m}^{3}\right)$ and the daily average flow $\left(\mathrm{m}^{3} \cdot \mathrm{s}^{-1}\right)$ reported in the fluviometric station for the same day of TP sample. Then, these loads were compared to the ones obtained according to Equation 1, considering the same time period. The model performance was evaluated by using the Nash-Sutcliffe coefficient (NSE).

\subsection{Statistics and uncertainty analysis}


The load estimation process, applied through Equation 1, might arise uncertainties mainly from hydrological parameters and water quality data (Hollaway et al. 2018). With regards particularly to the estimation of the load of dry period, ideally, the uncertainty analysis should integrate methodological uncertainty accounting the use of multiple methods of estimation and also the temporal and spatial variability (North et al. 2015). Then, an uncertainty analysis was assessed to ensure the obtained results.

Firstly, a consistency analysis of the TP concentration data was performed, in search of identify values possibly out of the range of representativeness for this parameter. This is particularly important since errors exclusively due to variability of $\mathrm{P}$ concentrations can be, at least, 20\% on average (Nürnberg et al. 2012). Besides, considering the limiting value of $4000 \mu \mathrm{g} . \mathrm{L}^{-1}$ for TP concentration in wastewater (Sperling 2007), values over this limit were excluded.

The variations in TP concentrations between the two studied periods (dry and wet) were statistically analyzed with Kruskal-Wallis and Mann-Whitney tests. The Shapiro-Wilk normality test was primarily applied to verify the behavior of the data. However, the non-parametric test was particularly suitable due to the unequal length of observations within each period. These same statistical tests were performed to evaluate differences between epilimnion TP concentrations and those measured in other depths. Although epilimnion concentration was used to perform the mass balance due to the relatively high monitoring frequency and large amount of data in comparison with deeper measurements, these tests allowed to reinforce the representativeness of the epilimnion concentration for the water column at the sampling points. This aspect also reinforces the assumed complete mixing hypothesis behavior. Pairwise comparisons were performed with statistical packages in Python programming.

The TP loads were estimated throughout the studied period for each reservoir. Therefore, the coefficient of variation was calculated for each one, as well as the bias existing between each modeled value and the reference load. The results were used to support a further quality analysis of this statistics parameters considering the available literature for TP load estimation. Furthermore, as the validation through the single field TP load data was recognized as a strong hypothesis, a literature review was carried out to gather and evaluate reported mean error values for the ECM methodology.

\section{$\underline{\text { 2.5 Correlation analysis }}$}

The TP load presents some well-known characteristics and strong correlations with parameters related to the catchment or the reservoir. Firstly, larger catchments have the potential to produce more TP load (Marques et 
al. 2019). Additionally, there is a relation between phosphorus pollution from nonpoint sources with flow conditions, as runoff events widely contribute on P load to rivers (Greene et al. 2011). In contrast, it is important to highlight that the complex behavior of the internal load brings more undefined correlations with these parameters. Finally, some particular correlations between internal and external load were also reported in literature (Nürnberg et al. 2012). Aiming at exploring the existence of similar relationships in the studied area, a correlation analysis was carried out between TP load and catchment area, load of wet period and reservoir inflow, load of dry period and reservoir volume, and loads of the wet and dry periods. The goodness of fit was evaluated trough the Pearson's correlation coefficient.

\section{Results and discussion}

\subsection{Catchment and reservoir hydrology}

The variation of the volume and the inflow regime of each reservoir for the studied period are presented in Fig. 2. The interannual variability of the reservoirs' volume can be observed in the large range of variation of the boxes. The reservoirs Orós, Catanhão and Banabuiú differed from the others with the highest stored volumes in the period. Their median volume was roughly $1,363 \mathrm{hm}^{3}$ while the maximum median volume after them was $79.95 \mathrm{hm}^{3}$ for the Edson Queiroz. The reservoirs Colina, Flor do Campo and Rivaldo de Carvalho achieved critical volumes in the studied period with minimum volumes ranging from 0.01 to $0.04 \mathrm{hm}^{3}$. These reservoirs are the smallest ones and become nearly empty on a yearly basis, which makes them "annual reservoirs". Contrastingly, the larger and more resilient ones (Orós and Castanhão) are considered "interannual reservoirs" (Lopes et al. 2014; Campos et al. 2016; Lacerda et al. 2018).

Fig. 2 Main hydrologic variables of each reservoir for the studied period

Regarding the mean inflow, the sum of the mean streamflow from the rivers and tributaries flowing to the reservoir, a great variation of flow regime was observed. The reservoir Olho D'água presented the lowest values, from 0.003 to $3.07 \mathrm{~m}^{3} . \mathrm{s}^{-1}$, while the Castanhão catchment produced the highest ones, from 0.11 to 549.13 $\mathrm{m}^{3}$. $\mathrm{s}^{-1}$. Additionally, some catchments could be grouped by similar characteristics in the period. The reservoirs Cachoeira, Arrebita and Forquilha, with the smallest catchments and an average precipitation on record of 916, 1,063 and $679 \mathrm{~mm} . \mathrm{yr}^{-1}$, respectively, presented similar inflow patterns in the period, from 0.008 to $14.97 \mathrm{~m}^{3} . \mathrm{s}^{-1}$ in average. 
Similarly, the reservoirs Angicos and Acarape do Meio presented similar patterns, from 0.007 to 14.44 $\mathrm{m}^{3} \cdot \mathrm{s}^{-1}$ in average, with median inflows of 0.63 and $0.69 \mathrm{~m}^{3} \cdot \mathrm{s}^{-1}$ and catchment areas of 285.62 and $210.01 \mathrm{~km}^{2}$, respectively. In contrast, the catchment of the reservoirs Rosário, Rivaldo de Carvalho, Colina and Flor do Campo, tough, have shown a more anomalous behavior compared with the others. Rosário presented a small variability while the remaining presented low values of inflow. It is noteworthy that the catchments of Flor do Campo and Colina share similar climatic characteristics due to their proximity (less than $40 \mathrm{~km}$ ). They have average precipitations of $577.1 \mathrm{~mm} \cdot \mathrm{yr}^{-1}$ and $615.4 \mathrm{~mm} \cdot \mathrm{yr}^{-1}$, respectively, which are very low and, as a consequence, contribute with low inflow rates.

Changing in precipitation levels throughout years are the main driver for interannual variability in reservoir volume and inflow in the State of Ceará (Broad et al. 2007), as a decline in the mean inflow is expected mostly during low precipitation periods (Zhang et al. 2015). Besides, the reservoirs have experienced a dramatic reduction on their volume due to the prolonged drought during the studied period (Lacerda et al. 2018, Wiegand et al. 2020). Mamede et al. (2018) also highlight the reservoirs' density in the watersheds of Ceará as a contributing characteristic to the inflow variabilities. This once the reduction of the contributing area to downstream and strategic reservoirs reduces the inflow consequently.

\subsection{Water quality characteristics}

The variation of the TP concentration in the water column was evaluated for the eighteen studied reservoirs from measurements at the sampling points near the dams. The dataset collected encompasses the entire studied period. Fig. 3 summarizes this result for four reservoirs. They were selected because of their depth range from the shallowest to the deepest reservoir. The vertical profile of the mean concentration for each season for the studied period is presented along with standard errors. In the wet period, the mean concentration in the water column varied from 37.39 to $533.86 \mu \mathrm{g} . \mathrm{L}^{-1}$, with a median of $67.87 \mu \mathrm{g} . \mathrm{L}^{-1}$. In the dry period, the ranges were from 27.73 to $227.35 \mu \mathrm{g} . \mathrm{L}^{-1}$ with a median of $61.93 \mu \mathrm{g} . \mathrm{L}^{-1}$. The statistical analysis was performed between the two datasets encompassing all measurements in the wet and dry periods. The results indicated no significant p-value to support differences in TP concentration between these periods $(\mathrm{p}<0.05)$ for seventeen reservoirs, except Colina. Temperate regions, on contrary, consistently report summer P concentrations as usually larger than annual averages in eutrophic shallow lakes with internal load (Nürnberg et al. 2012).

Overall, it was observed that the mean concentration for the two seasons is very similar for more than $90 \%$ of the reservoirs. This was attributed to a trade-off between the hydrological and limnological processes 
occurring in the two seasons, following the dynamics described by Eq. 1. While in the wet period the total load, reservoir volume and flushing rate are expected to be higher, in the dry period, all these parameters are expected to be lower. On the other hand, while in the wet period the retention time is expected to be lower and, consequently, the settling loss rate higher, the contrary is expected to occur in the dry period (see Eqs. 2, 3 and 4).

Fig. 3 TP concentration in the water column for the sampling point near the dam of the reservoir (a) Itaúna, (b) Sítios Novos, (c) Acarape do Meio e (d) Castanhão. Averages from 2008 to 2019 and standard errors (bars) are presented

Additionally, the Mann-Whitney and Kruskal-Wallis tests performed between the values in the upper surface $(0.3 \mathrm{~m}$ deep) and the values in the other depths presented significant p-values for $50 \%$ of the reservoirs $(\mathrm{p}<0.05)$. This suggests that for some reservoirs there is a marked mixing behavior and similar TP concentration between upper and lower layers as shown in Fig. 3. It is important to highlight that the mixing state, mainly in polymictic lakes, might be variable among years (Nürnberg 2009). Then, this phenomenon of TP concentration mixing in the water column might vary between years and seasons. Specifically, in the Castanhão reservoir, previous studies indicate that TP concentration measurements present similar values between surface and bottom waters, but with a slight increase towards the bottom (Lacerda et al. 2018).

High tributary inputs of $\mathrm{P}$ and release from anoxic sediments might be sources of contribution to the vertical variation of phosphorus concentration in the water column (Nürnberg et al. 2013). P released from sediments has the potential to increase phosphorus concentration from processes such as diffusion and/or water column mixing and, especially under anoxic conditions, when it can also mix into the epilimnion (Nikolai and Dzialowski 2014). Particularly for the studied period, while a drought event was in course, stronger mixing conditions occurred. The reduction of volume during drought events and the consequent decrease in water depth might have led to breaking of the thermocline due to wind forcing and contributed to the mixing in the entire water column (Lacerda et al. 2018). Additionally, the effect of wind shear under relatively shallow water conditions potentially caused wind-induced resuspension of sediment and phosphorus, as already pointed out by Araújo et al. (2019) and Mesquita et al. (2020). It is important to highlight that the analysis in the present study was performed for the sampling points near the dams. Hence, spatial variabilities might pose differences for other regions of the reservoirs. 


\subsection{Impact of the drought period in the TP concentration and reservoir volume}

Figure 4 presents the temporal distribution of volume, inflow, TP concentration and wet/dry period loads for the reservoir Edson Queiroz in the studied period. This reservoir was chosen since it presents typical characteristics of all the eighteen studied reservoirs. The period of remarkable low inflows encompassing from 2011 to 2017 is similar to all others reservoirs along with the increase in the TP concentration. During this period, they all also presented a drastic volume reduction. For the reservoir Edson Queiroz, the remaining volume at the end of 2016 represented $17.6 \%$ of the initial volume in 2011 , a reduction from $152.5 \mathrm{hm}^{3}$ to $26.9 \mathrm{hm}^{3}$. The largest and strategic reservoirs Orós, Castanhão and Banabuiú were those which caused more concerns about their volume reduction. At the end of 2016 they reached $16.4 \%, 5.3 \%$ and $0.46 \%$ of their total volume, respectively.

The observed depth reduction during the dry season (considering the difference in water level between the two dates on which the TP measurements were performed) was on average $1.3 \mathrm{~m}$, varying from $0.32 \mathrm{~m}$ to 5.53 $\mathrm{m}$. The reservoir that showed the highest level variation was Banabuiú (5.53 m between July and November 2014) and Castanhão (3.66 m between August and December 2015). In fact, drought periods can cause large variations in water levels, which consequently might cause changes in the physical, chemical and biological characteristics of the waterbodies (Moss 2011).

Fig. 4 Time series of volume, inflow, TP concentration and wet/dry period loads for the reservoir Edson Queiroz

From the wet period of 2017 the inflow pattern increased drastically presenting a peak of $21.46 \mathrm{~m}^{3} \cdot \mathrm{s}^{-1}$ which was 18 -fold higher than the average inflow of wet period since 2010. During the wet period of 2017 the highest TP concentration was also measured $\left(314 \mu \mathrm{g} \cdot \mathrm{L}^{-1}\right)$. As already pointed out herein, in waterbodies with a high level of trophy, sediment resuspension by storm events favor nutrient resuspension and thus an increase in the TP concentration (Seitz et al. 2020). Additionally, higher loads were observed from the increase in inflow as annual external P loading is strongly related to storm events (Carpenter et al. 2014; Rattan et al. 2017).

The TP concentration has showed a pattern of continuous increase from 2011 to 2017 , from $34 \mu \mathrm{g} . \mathrm{L}^{-1}$ on February-2011 to $161 \mu \mathrm{g} . \mathrm{L}^{-1}$ on April-2016, while the reservoir volume decreased continuously, as the studied region faced a prolonged drought period (Wiegand et al. 2020). Cavalcante et. al (2018) analyzed two semiarid reservoirs during drought period and observed the highest TP concentration values during the periods with lower depth. Extended droughts, particularly, have an important role in water quality deterioration due to increasing concentrations of nutrients (Lacerda et al. 2018). 
Figure 4 also shows the mean modeled TP load for each semester throughout the studied period. As already mentioned, the load during the dry period can be caused by both sediment release and/or resuspension (Mesquita et al. 2020; Moura et al. 2020). Particularly in shallow lakes, internal loading can promote elevated TP values in the epilimnion (Horppila et al. 2017). During the drought period, the water level of the studied reservoirs decreased significantly while the TP concentration in the epilimnion increased continuously. Accordingly, higher TP loads were found. The average relation between the load of the wet period and the load of the dry one was about $58.3 \%$ in this period. This might suggest the influence of the low depth in this process. Cavalcante et. al (2018) also reported the highest observed TP concentration during periods with low depth. Additionally, changes in lake size, depth, and climate potentially affect the level of the critical nutrient and can facilitate a regime shift in the ecosystem (Seitz et al. 2020).

The wet season, on the other hand, presents a load 2.58-fold higher, in average, than that of the dry season. This loading type is highly variable depending on the changes in discharge and is highest during storm events (Song et al. 2017). As observed in Fig. 4, once the inflow levels started to recover after the intense drought period, higher loads were obtained, with peak values of about 4.33 ton.month ${ }^{-1}$. Meanwhile, it is known that storm events in the dry period might contribute to over than $80 \%$ of the annual external P loading (Carpenter et al. 2015). Furthermore, the higher values of wet period load from 2017 highlight the importance of non-point sources of pollution for the waterbodies in semiarid regions. They are frequently the main external source of nutrients to reservoirs during the rainy period (Medeiros et al. 2015; Cavalcante et al. 2018).

\subsection{TP concentrations and mass balance estimates}

The epilimnion TP concentration measured in the wet and the dry period of each reservoir is presented in Fig. 5a. It is also shown the limit TP concentration for Class II according to national standards for lentic waterbodies (Brazil 2005). The waterbody classification considers to which purpose the water can be used for. Class I indicates the highest water quality level for noble uses and Class III is for consumption after enhanced treatment. All studied reservoirs are classified as Class II. Additionally, Fig. 5b shows the modeled TP load for the wet and the dry period along with the reference TP load value estimated by COGERH. The load of reference was used to strengthen the modeled estimations obtained in the present study. It is noteworthy that, although internal load is typically ortho-phosphate release, due to some difficulties in the determination of $\mathrm{P}$ speciation or in anoxic waters it is suggested its quantification as a mass of total phosphorus (Nürnberg 2009). 
Fig. 5 Epilimnion TP concentration (a) and modeled TP loads (b) for the dry and wet periods

All studied reservoirs remained eutrophic or hypereutrophic during great majority of the studied period (COGERH 2020a). The epilimnion TP concentrations for the dry period varied from 2 to $194 \mu \mathrm{g} . \mathrm{L}^{-1}$ in Angicos. This reservoir showed the highest percentage of good trophy state remaining over than $47.8 \%$ under mesotrophic classification. On the other hand, Colina have had the highest concentrations, from 44 to $599 \mu \mathrm{g} . \mathrm{L}^{-1}$, remaining over than $76.9 \%$ in eutrophic or hypereutrophic classification. The high values of concentration also extend to the wet period. In comparison to the limit of $30 \mu \mathrm{g} . \mathrm{L}^{-1}$, there is a common disrespect to reach this standard. As can be observed in Figure 5, only $16.7 \%$ of the waterbodies have roughly $30 \%$ of their dataset under this limiting value. It is important to highlight that, based on an outlier analysis, uncommonly high TP concentrations $\left(>4000 \mu \mathrm{g} . \mathrm{L}^{-1}\right)$ were excluded as they were probably a result of some sampling error.

The Kruskal-Wallis test performed between the concentrations in the wet and dry periods for each reservoir presented significant p-values only for the reservoirs Colina and Banabuiú $(\mathrm{p}<0.05)$. For Banabuiú the concentrations in the dry period were higher than in the wet one. The opposite situation was verified for Colina. Higher summer concentration is widely common mainly as a result of the internal TP load influence (North et al. 2015) once this loading affects surface water quality in shallow polymictic lakes (Kowalczewska-Madura et al. 2019). Colina is the shallower reservoir among the eighteen studied while Banabuiú is the third largest. However, during the drought period, these reservoirs had such a decrease in their volume and depth that they achieved a percentual volume under $0.23 \%$ in 2015 for Colina and 0.4\% in 2016 for Banabuiú.

It is important to highlight, then, that the general analysis of the grouped dataset of TP concentration in the wet and dry seasons has not presented statistically significant differences for $88.9 \%$ of the reservoirs. However, the analysis carried out in an annual timestep in each reservoir for paired TP concentration comprised in the dry period showed that the great majority of the pairs presented a slightly higher TP concentration at the end of the dry period. This aspect might be a combined result of the volume reduction, which concentrates the nutrients, as well as an evidence of internal load (Nürnberg et al. 2012; Cavalcante et al. 2018).

With regards to the load estimated during the wet seasons, the values varied from the minimum of 0.015 ton.month ${ }^{-1}$ in Olho D’água to 34.76 ton.month $^{-1}$ in Castanhão, with a mean value of 2.81 ton.month ${ }^{-1}$. Some exceptionally high modeled TP load were obtained and it is probably an overestimate due to an extremely high, single TP concentration value. Such aspect emphasizes the uncertainty associated with the method applied to estimate the TP load. High values were obtained for larger catchments as they have the potential to produce more 
TP load mostly from nonpoint sources (Marques et al. 2019). Specifically, for the Castanhão catchment, several studies were carried out. The agriculture contribution in this catchment was estimated around 116 ton. $\mathrm{yr}^{-1}$, in average 9.67 ton.month ${ }^{-1}$ (Paula Filho et al. 2019). Lacerda et al. (2018) estimated 212 tons as a flux of TP load for the Castanhão reservoir for the six-month of the wet period (35.33 ton.month ${ }^{-1}$ ) from measured TP concentration and inflow. In some highly eutrophic systems, such as the studied reservoirs, large portion of the load from the wet period possibly settles and becomes recycled within the same year which might resemble sediment-released P (Nürnberg 2009). Thus, due to the settling process, only a certain percentage of external load can effectively contribute to lake water TP (Nürnberg et al. 2013).

Additionally, it can be seen in Fig. 5 that the estimated values were slightly under the reference load for the catchments, and more significantly underestimated for $22.22 \%$ of them, represented by the catchments of the reservoirs General Sampaio, Rosário, Angicos and Banabuiú. For the remaining, the reference value was very close to the value reported by COGERH or in the range of the modeled TP load. The correlation between the mean modeled TP load and the reference load for the reservoirs resulted in a $\mathrm{R}^{2}=0.82$ with a bias varying from $2.9 \%$ to $95.2 \%$ with an average of $65.0 \%$. The underestimation of the TP load in some catchments may be due to the temporally spaced sampling data, only three or four times per year, which tend to underrepresent peak storm or high-flow events. This way, the likely intense phosphorus dynamics in the waterbody that happen at the moment and in a short period after it may not be accounted (Johnes 2007; Bowes et al. 2009). Moreover, the reference load was estimated in a period with higher inflow levels (from 2008 to 2011 depending on the reservoir) than the average of the studied period, then possibly accounting more external load.

Concerning to the load of dry period, the estimates varied from the minimum of 0.016 ton.month $^{-1}$ in Rivaldo de Carvalho to 31.19 ton.month ${ }^{-1}$ in Castanhão, with a mean value of 1.09 ton.month ${ }^{-1}$. The modeling process resulted in $14 \%$ of negative estimates in average with a maximum of $48 \%$ for the Acarape do Meio reservoir. Positive values indicate that internal P loading occurs in the sediment whereas negative values imply $\mathrm{P}$ retention (Song et al. 2017). As can be observed in Fig. 5, the load estimated during the dry period is of the same order as those of the wet period for the majority of the reservoirs. Lepori and Roberts (2017) suggest that deep lakes should be less affected by internal loading than shallow ones, once deep lakes have a larger volume of water to dilute the P released from the sediments. However, the studied reservoirs have faced a drastic volume reduction, which corroborate to the high values of load produced during the dry season even in once deep reservoirs. Additionally, due to the climatic conditions of the studied area and the complete dryness of the rivers in the dry season, no inflow arrive in this period. Then, significant external inputs of nutrients are not expected (Barbosa et 
al. 2012). So, internal loading represents the main source of $P$ load to lakes and reservoirs during dry periods (Nürnberg 2009).

The observed among-catchment variation of TP flux for the load of wet period can be largely explained by differentiated net anthropogenic $\mathrm{P}$ input as well as seasonal variations of water discharge in the rivers (Han et al. 2018; Hu et al. 2020). For the load of dry period it may depend on climatic conditions and the level of oxygenation in the water-sediment interface (Cavalcante et al. 2018). Additionally, the existence of aquaculture is another relevant aspect, as it releases nutrients directly to the water column (Santos et al. 2016). This contributes to the water quality deterioration, particularly during extended drought periods (Oliveira et al. 2015). In the Castanhão reservoir, the aquaculture may contribute to roughly 163 ton.yr ${ }^{-1}$, in average 13.58 ton.month ${ }^{-1}$ (Lacerda et al. 2018). With regards to the among-season variations, a trade-off between the $\mathrm{P}$ mechanisms, notably the physical processes, might contribute to similar estimates. During the wet season, the wind effect is weakened in comparison to the dry season, which might impact wind-induced resuspension. However, the external transport is markedly impactful during the wet period, once there has been no or little outflow/overflow during the dry season (specially during the drought period). With respect to others mechanisms mainly occurring in the water-sediment interface (such as diffusion, adsorption and desorption), they may be better discussed once gross estimates are obtained through core incubation, while in this study only net estimates through mass balance were performed.

Following Vollenweider (1968) and Chapra (2008), areal phosphorus loads were obtained and the rates are expressed in terms of total P. Table 2 presents the average values estimated for each reservoir. The areal loads ranged from 0.07 to $1.04 \mathrm{gP} . \mathrm{m}^{2} . \mathrm{month}^{-1}$ for the wet season and from 0.05 to $0.65 \mathrm{gP} . \mathrm{m}^{2} . \mathrm{month}^{-1}$ for the dry season. For the dry period, the literature reports rates ranging between 0.11 and $0.30 \mathrm{gP} \cdot \mathrm{m}^{2} \cdot \mathrm{month}^{-1}$ with higher rates for eutrophic water bodies (Nürnberg et al. 2012; Nürnberg et al. 2013). High release rates are more common in eutrophic lakes (Qin et al. 2016). The annual averages varied from 0.66 to $7.29 \mathrm{gP} . \mathrm{m}^{2} . \mathrm{yr}^{-1}$. These values are consistent with the ones reported in the literature: $0.15 \mathrm{gP} . \mathrm{m}^{2} . \mathrm{yr}^{-1}$ (Nürnberg et al. 2012), $5.00 \mathrm{gP} . \mathrm{m}^{2} . \mathrm{yr}^{-1}$ (Ahlgren et al. 1988), $5.90 \mathrm{gP} \cdot \mathrm{m}^{2} \cdot \mathrm{yr}^{-1}$ (Köhler 2005), and $7.06 \mathrm{gP} \cdot \mathrm{m}^{2} \cdot \mathrm{yr}^{-1}$ (Nürnberg 1984).

Because of the dense reservoir network of the Brazilian semiarid, the mineral sedimentation (reservoir silting) is only about $20 \%$ of the rates observed in other reservoirs globally, as reported by Lima Neto et al. (2011). However, in the reservoirs studied here, the net sedimentation rate of total phosphorus ranged from about 60 to $90 \%$ of the input load, contrasting with an average of about $40 \%$ obtained for temperate lakes and reservoirs (Hejzlar et al., 2006). This higher net sedimentation rate of TP is attributed to the higher water temperature of the Brazilian semiarid reservoirs, which leads to a combined effect of increased P consumption by algae and increased 
physical sedimentation due to reduced water viscosity, corroborating the results of Toné and Lima Neto (2020). The above results indicate that $\mathrm{P}$ retention in the high-density reservoir network is potentially counterbalanced by the higher net sedimentation rates due to higher water temperatures, possibly resulting in similar areal P loads (up to about $\left.7 \mathrm{gP} \cdot \mathrm{m}^{2} \cdot \mathrm{yr}^{-1}\right)$, as reported by Ahlgren et al. (1988), Köhler (2005) and Nürnberg et al. $(1984,2012)$.

Table 2 Mean areal phosphorus load for the wet and dry seasons and total annual load

\subsection{Load of dry season vs. load of wet season over the annual P budget.}

Fig. 6 shows the predominance by type of TP load for each reservoir. This estimate represents the average of the estimated values per period. The predominance of the dry period load varied from $6.56 \%$ in Cachoeira to 62.74\% in Flor do Campo. For the reservoir Acarape do Meio, the second with the lowest dominance of dry period load, several studies in its catchment identified the intensity of external input mainly from point sources. Open-air dumps, illegal slaughterhouses and four STW from which three discharge their effluents directly into the main rivers were identified in the catchment of Acarape do Meio (Lima et al. 2016). For the Orós and Castanhão reservoirs, in spite of the intense fish farming practice, they have larger and rural catchments $\left(>24000 \mathrm{~km}^{2}\right)$ that concentrate the most relevant irrigated croplands of the state. Consequently, there is a high amount of TP production from nonpoint sources (CEARÁ 2020b). Similar analysis apply for the Banabuiú reservoir.

A growing predominance of dry period load is observed in Fig. 6. From Arrebita reservoir it surpasses $50 \%$. The most relevant characteristic of these unmentioned reservoirs that can contribute with these results is the volume reduction they have suffered during the studied period, as previously discussed. Furthermore, in normal conditions, the reservoirs already have a diurnal mixing cycle (Mesquita et al. 2020). The combination of the volume reduction with a complete mixing condition might turn the reservoirs close to shallow polymictic ones and recent literature provides evidence that polymictic lakes are more prone to have high internal $\mathrm{P}$ loading rates (North et al. 2015; Orihel et al. 2015). Furthermore, in some shallow lakes the phosphorus release from sediment into the water column can be controlled by the wind mixing (Cavalcante et al. 2018).

In the lake nutrient budget, sediment P might have an increasing predominance (Doan et al. 2018). Thus, representing the load produced during the dry season as a percentage of the total annual load is a way to facilitate the comparison with the load from the wet season and understand its importance (Nürnberg 2009). Song et al. (2017) highlights that in P enriched agricultural areas internal P loading can be as high as external one. The existence of high internal load production implies that the achievement of a stable mesotrophic condition will not 
occur until the substantial reduction of these loadings (Lepori and Roberts 2017). Moreover, it delays the decline of TP concentration expected once there is a reduction of external load. Meanwhile, it may take a very long time to deplete the internal loading, especially in reservoirs with a long history of pollution (Schindle 2006). It is expected that, in general, changes of the released $\mathrm{P}$ depend on the mixing regime of the lake, trophic state and chemistry (Nürnberg 2009). Additionally, higher amount of phytoplankton might be related with the amounts of released P (Kowalczewska-Madura et al. 2019).

An assessment of the internal loading percentage over the annual $\mathrm{P}$ load budget reported for other waterbodies was carried out. This dominance were around 2\%-4\% (Lepori and Roberts 2017), 3\%-7\% (Matisoff et al. 2016), 12\%-14\% (Song et al. 2017), 39\% (Nikolai and Dzialowski, 2014), 59.59\% (Kowalczewska-Madura et al. 2019), 60\% (Nürnberg et al. 2012) and 45\%-89\% (Nürnberg et al. 2013; Loh et al. 2013). These results reinforce that, depending on several aspects as already discussed, the internal TP load can be as high as the external load and become another important source of water quality degradation.

Fig. 6 Assessment of the representativeness of the loads produced in the wet and dry seasons in the annual TP load

\subsection{Predictive models for TP load input}

Simple predictive models were proposed as an attempt to assess the most correlated characteristics with the TP load. The correlations were developed between the TP load of dry period and volume, TP load of wet period and inflow, TP load of dry period and TP load of wet period, and Total TP load and catchment area. Figure 7 presents the models as well as the coefficient of determination for each one. The models were adjusted with mean values to reduce the bias, once the fitting with the entire dataset including the modeled values of all reservoirs presents a large variability. A satisfactory $\mathrm{R}^{2}$ was obtained through a power-low curve adjustment. The residual analysis, in order to reinforce the quality of the models, was performed graphically. Emphasis was given on evaluating the homoscedasticity of the model and the existence of outliers.

Figure 7(a) presents a positive correlation between the TP load of dry period and the reservoir volume $\left(\mathrm{R}^{2}=0.82\right)$. A possible explanation relies on the relation between the reservoir volume and the water-sediment interfacial area. A larger volume enlarges this interface and $\mathrm{P}$ production by release under appropriate conditions. Moreover, several aspects may be linked to this result. Larger reservoirs also have larger catchments in the study 
area. The reservoirs with this characteristic receive significant contributions of external load, and it can be seen in Fig 7 (c) that greater load in the wet period implies in greater load in the dry period. Thus, its positive correlation with the volume might also be influenced by this chain of aspects.

The positive correlation between the TP load of wet period and the inflow $\left(\mathrm{R}^{2}=0.69\right)$ is largely known [Fig. 7(b)]. This type of load is adequately explained by seasonal variations of water discharge in the rivers (Han et al. 2018), as stream discharge is a fundamental explanatory variable with a positive influence on TP load (Rattan et al. 2017). Hydrologic events, such as peak storms, mainly in watersheds dominated by non-point sources, significantly contribute to external TP load (Jeznach et al. 2017). Its rates during peak flow events can be approximately five times higher than under normal conditions (North et al. 2015).

As shown in Fig. 7(c), the dry and wet period loads were directly correlated $\left(R^{2}=0.79\right)$. The higher the TP inputs during the wet period, the higher those in the dry one. This positive correlation indicates that an abatement of external P sources implies an almost immediate decrease to internal load. This also highlights the strong influence of the load produced during the wet period with that produced during the dry period. According to Nürnberg (2009), the wet period load is more susceptible to settle and be recycled within the same year in highly eutrophic systems. As the studied reservoirs remained highly eutrophic during the studied period, this aspect strengthens the obtained correlation. In contrast, an inverse correlation between these variables can also be found (Nürnberg et al. 2012).

Finally, the catchment area was shown as an important predictor of the total TP load entering a waterbody $\left(\mathrm{R}^{2}=0.66\right)$, as depicted in Fig. 7(d). It is commonly expected and observed that larger catchments might produce more TP load, especially if there is an intensive agriculture exploitation on the lands (Marques et al. 2019). Additionally to agriculture, soil erodibility also plays an important role in the mobilization of pollutants (Li et al. 2020). Poorly drained soils can transfer the most diffuse P load (Greene et al. 2011), particularly for semiarid watersheds (Paula Filho et al. 2019).

Fig. 7 Proposed models for the (a) TP load of dry period as function of the volume, (b) TP load of wet period as function of the inflow, (c) TP load of dry period as function of the TP load of wet period and (d) Total TP load as function of the catchment area

The ultimate analysis performed was the estimation of the TP load through a concentration - flow relationship particularly for the Castanhão reservoir. Thus, a comparison between the load obtained through 
calibration of the Equation (1) with the one obtained through the concentration - flow relationship was performed. It is important to highlight that this validation was possible only for the load modeled in the wet period once the existence of significant inflow occurs primarily in the first semester of the year. Figure 8 presents the comparison of the modeled loads encompassing the period from 2013 to 2019 . The estimated loads varied from 0.002 to 51.03 ton.month ${ }^{-1}$ for the concentration - flow relationship modeling approach and from 0.24 to 34.99 ton.month ${ }^{-1}$ for the mass balance approach [Eq. (1)]. The metric NSE between the models was 0.67 , which turned the quality of the adjustment satisfactory (Moriasi et al. 2007).

The most distant result between the models was obtained for the estimation in 2015. In the dry period of this year, the reservoir presented a very low volume (result of the prolonged period of low flows) and high measured TP concentrations. This implied a higher load estimate by the model of Vollenweider. On the other hand, the low flow rates measured in the river resulted in lower load estimates by the flow-concentration model. Combined, these factors enlarged the difference between the models. However, considering the overall comparison of the results, the classic predictive model of Vollenweider is properly capable to perform a good estimation for the external TP load, once this load type has formed the basis of development for this model (Schauser and Chorus 2009).

Fig. 8 Comparison of the total TP load input to the Castanhão reservoir by using two different approaches

\subsection{Uncertainty, implications and limitations of the model}

The high variations in water level and inflow turn the internal TP load estimation particularly challenging for complex managed reservoirs (North et al. 2015). The variability of the modeled loads was evaluated by the coefficient of variation. It ranged from 0.09 to 2.03 with mean of 0.70 for the load of dry period and from 0.40 to 2.08 with mean of 0.99 for the load of wet period. This variation is markedly high in comparison to reported range of around 0.05-0.23 for other studies (Kulasova et al. 2012). However, the high variation in the present study is within presented ranges of variation, especially for the wet period load. It might range from $30 \%$ to $110 \%$ for an average and maximum typical scenario, respectively (Harmel et al. 2006). Additionally, uncertainties related to discharge measurements, sample collection, preservation and laboratory analysis as well as general model parameterization can also influence the results. Sample collection adds an uncertainty of about $100 \%$ in the worst scenario for total phosphorus concentration (Harmel et al. 2006). Data aggregation such as the use of average concentrations also accounts in $13 \%$ of uncertainty (Harmel et al. 2009). 
Regarding to the reference TP load, previous studies that have already applied the ECM reported a mean error ranging from 4.3\% to 31\% (Johnes 1996; Ding et al. 2010; Matias and Johnes 2012; Delkash and Al-faraj 2014; Greene et al. 2015; Tsakiris and Alexakis 2015). Then, for the catchments whose reference load was underestimated this range of mean error in computing the reference TP load might be taken into consideration. Besides, for the most distant results, variations in the input data to the modeled load may have had greater influence on this difference. For seasonal and spatial data, the monitoring frequency, quality and quantity significantly contribute to the accuracy of the load assessment (Nürnberg 2009). Error exclusively due to variability of P concentrations is at least $20 \%$ on average for lake samples (Nürnberg et al. 2012).

Existing limitations are mainly related with TP load estimation, since the developed models rely on the accuracy of the extensive field study carried out by COGERH. It has to be highlighted, though, that the data limitation on the studied area largely reduce the range of possible useful alternatives to perform a data comparison and validation. Additionally, sampling interval, analysis and data quality manipulation inaccuracies in reservoirs' data can have an impact in the load estimation process and in the modeled outputs. Moreover, in the data frequency of roughly twelve years of sampling in reservoirs, high flow events remained under-represented. Only five years in the studied period presented precipitation indexes roughly above the average in all catchments. Thus, low to medium flow were more frequent in the study dataset which may have reduced the possible amount of TP load produced in the wet season.

\section{Conclusions}

The analysis of seasonal TP concentrations between the wet and dry periods resulted in insignificant differences $(\mathrm{p}<0.05)$ for $88.9 \%$ of the reservoirs, which was attributed to a trade-off between the hydrological/limnological processes occurring in the two seasons. However, a slightly higher TP concentration at the end of the dry period was observed. The statistical tests performed between the concentrations in the upper surface $(0.3 \mathrm{~m}$ depth) and in the other depths also revealed no significant p-values for $50 \%$ of the reservoirs $(\mathrm{p}<0.05)$. This suggests that many reservoirs tended to present a well-mixed behavior. Then, a complete-mix mass balance model was applied. For the dry period, the modeling process resulted in only $14 \%$ of negative TP load estimates on average. While negative values imply $\mathrm{P}$ retention, positive ones indicate that internal $\mathrm{P}$ loading occurred. The results also indicated that a high amount of load from the dry period contributed to the annual budget, with estimates varying from 0.016 to 31.19 ton.month ${ }^{-1}$. The predominance of the dry period load over the annual TP input varied from 6.56 to $62.74 \%$. This suggests that the eutrophic state and shallow water condition of the 
studied reservoirs have possibly contributed to the settling and recycling of the external load within the same year. The areal TP load estimates ranged from 0.66 to $7.29 \mathrm{gP} \cdot \mathrm{m}^{2} \cdot \mathrm{yr}^{-1}$, consistently with the literature (0.146 - 7.06 $\left.\mathrm{gP} \cdot \mathrm{m}^{2} \cdot \mathrm{yr}^{-1}\right)$. This implies that TP retention in the dense reservoir network is potentially counterbalanced by the higher net sedimentation rates due to higher water temperatures. Power-law curves were adjusted between internal TP load and volume, internal and external TP loads, external load and inflow, and total TP load and catchment area, resulting in satisfactory $\mathrm{R}^{2}$ of $0.82,0.79,0.69$ and 0.66 , respectively. Despite the uncertainties involved in the estimations, the findings from this work are novel as the quantification of external and internal P loads was approximated by the estimation of the loads produced during the wet and dry periods, respectively. Additionally, their relative importance to the annual input load was evaluated and predictive correlations were proposed. This study not only advanced the knowledge of $\mathrm{P}$ dynamics in tropical semiarid reservoirs, but also provided evidences of important internal loadings to these systems. Furthermore, the methodology applied in the study might be directly applicable to water bodies with similar characteristics in other dryland regions.

\section{Declarations}

- Ethics approval and consent to participate:

Not applicable

- Consent for publication:

Not applicable

- Availability of data and materials:

The datasets used and/or analyzed during the current study are available from the corresponding author on reasonable request

- Competing interests:

The authors declare that they have no competing interests

- Funding:

The present study was supported through the Ceará State Research Foundation - FUNCAP [Research Grant PNE-

0112-00042.01.00/16] and the Coordination for the Improvement of Higher Education Personnel - CAPES [Research Grant PROEX 20/2020].

- Authors' contributions:

MJDR collected, analyzed and interpreted the data, and wrote the manuscript. IELN supervised the research, analyzed and interpreted the data, and revised the manuscript. All authors read and approved the final manuscript. - Acknowledgments:

The authors would like to thank the Water Resources Management Company of the State of Ceará (COGERH) for providing the data necessary for the analyses.

\section{References}


Ahlgren, I. Frisk, T. Lars Kamp-Nielsen, L. 1988. Empirical and theoretical models of phosphorus loading, retention and concentration vs. lake trophic state. Hydrobiologia. 170. 285-303.

Ansari, A.A., Gill, S.S., 2014. Eutrophication: Causes, consequences and control. Eutrophication Causes, Consequences Control Vol. 2 1-262. https://doi.org/10.1007/978-94-007-7814-6

APHA. American Public Health association. 2005. Standard Methods for the Examination Water and Wastewater. 21st Ed. Washington: APHA. 1083p.

Araújo, G.M., Lima Neto, I.E., Becker, H., 2019. Phosphorus dynamics in a highly polluted urban drainage channel-shallow reservoir system in the Brazilian semiarid. An. Acad. Bras. Cienc. 91. https://doi.org/10.1590/0001-3765201920180441

Barbosa, J.E. de L., Medeiros, E.S.F., Brasil, J., Cordeiro, R. da S., Crispim, M.C.B., da Silva, G.H.G., 2012. Ecossistemas aquáticos do semi-árido brasileiro: Aspectos limnológicos e manejo. Acta Limnol. Bras. 24, 103-118. https://doi.org/10.1590/S2179-975X2012005000030

Bowes, M.J., Smith, J.T., Jarvie, H.P., Neal, C., 2008. Modelling of phosphorus inputs to rivers from diffuse and point sources. Sci. Total Environ. 395, 125-138. https://doi.org/10.1016/j.scitotenv.2008.01.054

Bowes, M.J., Smith, J.T., Neal, C., 2009. The value of high-resolution nutrient monitoring: A case study of the River Frome, Dorset, UK. J. Hydrol. 378, 82-96. https://doi.org/10.1016/j.jhydrol.2009.09.015

Brasil. Ministério do Meio Ambiente. Conselho Nacional de Meio Ambiente, CONAMA. Resolução CONAMA no 431 357, de 17 de março de 2005. Disponível em: < http://www.mma.gov.br>. Acesso em: 10 de outubro de 2017.

Brasil. Instituto Nacional de Meteorologia. Normais climatológicas. 2020. Disponível em: < https://portal.inmet.gov.br/normais>. Acesso em: 17 jan. 2020.

Broad, K., Pfaff, A., Taddei, R., Sankarasubramanian, A., Lall, U., de Assis de Souza Filho, F., 2007. Climate, stream flow prediction and water management in northeast Brazil: Societal trends and forecast value. Clim. Change 84, 217-239. https://doi.org/10.1007/s10584-007-9257-0

Campos, J.N.B., Lima Neto, I.E., Studart, T.M.C., Nascimento, L.S.V., 2016. Trade-off between reservoir yield and evaporation losses as a function of lake morphology in semi-arid Brazil. An. Acad. Bras. Cienc. 88, 1113-1125. https://doi.org/10.1590/0001-3765201620150124

Carpenter, S.R., Booth, E.G., Kucharik, C.J., Lathrop, R.C., 2014. Extreme daily loads: role in annual phosphorus input to a north temperate lake. Aquat. Sci. 77, 71-79. https://doi.org/10.1007/s00027-014-0364-5

Castellano, L., Ambrosetti, W., Barbanti, L., Rolla, A., 2010. The residence time of the water in Lago Maggiore (N. Italy): First results from an Eulerian-Lagrangian approach. J. Limnol. 69, 2. https://doi.org/10.3274/JL10-69-1-02

Castagnino, W. A. Investigación de modelos simplificados de eutroficación en lagos tropicales. Organizacion Panamericana de la Salud, Centro Panamericano de Ingenieria Sanitaria y Ciencias del Ambiente, Versión Revisada. 1982.

Cavalcante, H., Araújo, F., Becker, V., 2018. Phosphorus dynamics in the water of tropical semiarid reservoirs in a prolonged drought period. Acta Limnol. Bras. 30. https://doi.org/10.1590/s2179-975x1617

Ceará. Companhia de Gestão dos Recursos Hídricos: Inventários ambientais. 2020b. Disponível em: <http://www.hidro.ce.gov.br/hidro-ce-zend/mi/midia/show/150>. Acesso em: 01 jan. 2020.

Ceará. Companhia de Gestão dos Recursos Hídricos: Monitoramento Quantitativo e Qualitativo dos Recursos 
Hídricos. 2020a. Disponível em: 〈http://www.hidro.ce.gov.br>. Acesso em: 13 fev. 2020.

Chapra, S.C., 2008, Surface Water-Quality Modeling, Waveland Press, Long Grove, IL, 835 p.

Chapra, S.C., Dolan, D.M., 2012. Great Lakes total phosphorus revisited: 2. Mass balance modeling. J. Great Lakes Res. 38, 741-754. https://doi.org/10.1016/j.jglr.2012.10.002

Chapra, S.C., Dolan, D.M., Dove, A., 2016. Mass-balance modeling framework for simulating and managing longterm water quality for the lower Great Lakes. J. Great Lakes Res. 42, 1166-1173. https://doi.org/10.1016/j.jglr.2016.04.008

Chaves, L.C.G., Lopes, F.B., Maia, A.R.S., Meireles, A.C.M., Andrade, E.M. de, 2019. Water quality and anthropogenic impact in the watersheds of service reservoirs in the Brazilian semi-arid region. Rev. Ciência Agronômica 50, 223-233. https://doi.org/10.5935/1806-6690.20190026

Delkash, M., Al-faraj, F.A.M., 2014. Comparing the Export Coefficient Approach with the Soil and Water Assessment Tool to Predict Phosphorous Pollution: The Kan Watershed Case Study. https://doi.org/10.1007/s11270-014-2122-7

Ding, X., Shen, Z., Hong, Q., Yang, Z., Wu, X., Liu, R., 2010. Development and test of the Export Coefficient Model in the Upper Reach of the Yangtze River. J. Hydrol. 383, $233-244$. https://doi.org/10.1016/j.jhydrol.2009.12.039

Doan, P.T.K., Watson, S.B., Markovic, S., Liang, A., Guo, J., Mugalingam, S., Stokes, J., Morley, A., Zhang, W., Arhonditsis, G.B., Dittrich, M., 2018. Phosphorus retention and internal loading in the Bay of Quinte, Lake Ontario, using diagenetic modelling. Sci. Total Environ. 636, 39-51. https://doi.org/10.1016/j.scitotenv.2018.04.252

Greene, S., Johnes, P.J., Bloomfield, J.P., Reaney, S.M., Lawley, R., Elkhatib, Y., Freer, J., Odoni, N., Macleod, C.J.A., Percy, B., 2015. A geospatial framework to support integrated biogeochemical modelling in the United Kingdom. Environ. Model. Softw. 68, 219-232. https://doi.org/10.1016/j.envsoft.2015.02.012

Greene, S., Taylor, D., McElarney, Y.R., Foy, R.H., Jordan, P., 2011. An evaluation of catchment-scale phosphorus mitigation using load apportionment modelling. Sci. Total Environ. 409, 2211-2221. https://doi.org/10.1016/j.scitotenv.2011.02.016

Han, C., Zheng, B., Qin, Y., Ma, Y., Yang, C., Liu, Z., Cao, W., Chi, M., 2018. Impact of upstream river inputs and reservoir operation on phosphorus fractions in water-particulate phases in the Three Gorges Reservoir. Sci. Total Environ. 610-611, 1546-1556. https://doi.org/10.1016/j.scitotenv.2017.06.109

Harmel, R.D., Cooper, R.J., Slade, R.M., Haney, R.L., Arnold, J.G., 2006. Cumulative uncertainty in measured streamflow and water quality data for small watersheds. Trans. ASABE 49, 689-701.

Harmel, R.D., Smith, D.R., King, K.W., Slade, R.M., 2009. Estimating storm discharge and water quality data uncertainty: A software tool for monitoring and modeling applications. Environ. Model. Softw. 24, 832842. https://doi.org/10.1016/j.envsoft.2008.12.006

Hejzlar, J., Šámalová, K., Boers, P., Kronvang, B. 2006. Modelling Phosphorus Retention in Lakes and Reservoirs. Water, Air, and Soil Pollution: 6, 487-494.

Hollaway, M.J., Beven, K.J., Benskin, C.M.W.H., Collins, A.L., Evans, R., Falloon, P.D., Forber, K.J., Hiscock, K.M., Kahana, R., Macleod, C.J.A., Ockenden, M.C., Villamizar, M.L., Wearing, C., Withers, P.J.A., Zhou, J.G., Barber, N.J., Haygarth, P.M., 2018. A method for uncertainty constraint of catchment discharge and phosphorus load estimates. Hydrol. Process. 32, 2779-2787. https://doi.org/10.1002/hyp.13217 
Horppila, J., Holmroos, H., Niemistö, J., Massa, I., Nygrén, N., Schönach, P., Tapio, P., Tammeorg, O., 2017. Variations of internal phosphorus loading and water quality in a hypertrophic lake during 40 years of different management efforts. Ecol. Eng. 103, 264-274. https://doi.org/10.1016/j.ecoleng.2017.04.018

Hu, M., Liu, Y., Zhang, Y., Shen, H., Yao, M., Dahlgren, R.A., Chen, D., 2020. Long-term (1980-2015) changes in net anthropogenic phosphorus inputs and riverine phosphorus export in the Yangtze River basin. Water Res. 177, 115779. https://doi.org/10.1016/j.watres.2020.115779

Kohler, J.; Hilt, S., Adrian, R., Nicklisch, A., Kozerski, H. P., Walz, N. 2005. Long-term response of a shallow, moderately flushed lake to reduced external phosphorus and nitrogen loading. Freshwater Biology. 50 (10) 1639-1650. http://dx.doi.org/10.1111/j.1365-2427.2005.01430.x.

Jeznach, L.C., Hagemann, M., Park, M.H., Tobiason, J.E., 2017. Proactive modeling of water quality impacts of extreme precipitation events in a drinking water reservoir. J. Environ. Manage. 201, 241-251. https://doi.org/10.1016/j.jenvman.2017.06.047

Johnes, P.J., 1996. Evaluation and management of the impact of land use change on the nitrogen and phosphorus load delivered to surface waters: the export coefficient modelling approach 183, 323-349.

Johnes, P.J., 2007. Uncertainties in annual riverine phosphorus load estimation: Impact of load estimation methodology, sampling frequency, baseflow index and catchment population density. J. Hydrol. 332, 241258. https://doi.org/10.1016/j.jhydrol.2006.07.006

Katsev, S., 2017. When large lakes respond fast: A parsimonious model for phosphorus dynamics. J. Great Lakes Res. 43, 199-204. https://doi.org/10.1016/j.jglr.2016.10.012

Kiani, M., Tammeorg, P., Niemistö, J., Simojoki, A., Tammeorg, O., 2020. Internal phosphorus loading in a small shallow Lake: Response after sediment removal. Sci. Total Environ. 725, 138279. https://doi.org/10.1016/j.scitotenv.2020.138279

Kowalczewska-Madura, K., Gołdyn, R., Bogucka, J., Strzelczyk, K., 2019. Impact of environmental variables on spatial and seasonal internal phosphorus loading in a mesoeutrophic lake. Int. J. Sediment Res. 34, 14-26. https://doi.org/10.1016/j.ijsrc.2018.08.008

Kulasova, A., Smith, P.J., Beven, K.J., Blazkova, S.D., Hlavacek, J., 2012. A method of computing uncertain nitrogen and phosphorus loads in a small stream from an agricultural catchment using continuous monitoring data. J. Hydrol. 458-459, 1-8. https://doi.org/10.1016/j.jhydrol.2012.05.060

Lacerda, L.D., Santos, J.A., Marins, R. V., Da Silva, F.A.T.F., 2018. Limnology of the largest multi-use artificial reservoir in NE Brazil: The Castanhão Reservoir, Ceará State. An. Acad. Bras. Cienc. 90, 2073-2096. https://doi.org/10.1590/0001-3765201820180085

Le Moal, M., Gascuel-Odoux, C., Ménesguen, A., Souchon, Y., Étrillard, C., Levain, A., Moatar, F., Pannard, A., Souchu, P., Lefebvre, A., Pinay, G., 2019. Eutrophication: A new wine in an old bottle? Sci. Total Environ. 651, 1-11. https://doi.org/10.1016/j.scitotenv.2018.09.139

Lepori, F., Roberts, J.J., 2017. Effects of internal phosphorus loadings and food-web structure on the recovery of a deep lake from eutrophication. J. Great Lakes Res. 43, 255-264. https://doi.org/10.1016/j.jglr.2017.01.008

Li, N.X., Xu, J.F., Yin, W., Chen, Q.Z., Wang, J., Shi, Z.H., 2020. Effect of local watershed landscapes on the nitrogen and phosphorus concentrations in the waterbodies of reservoir bays. Sci. Total Environ. 716. https://doi.org/10.1016/j.scitotenv.2020.137132

Lima, B. P. Framing of waterbodies in the Brazilian Northeast as an instrument for environmental management 
and sustainability: The case of the Acarape do Meio watershed in Ceará. $271 \mathrm{f}$. Thesis (Doctorate). Agricultural Engineering Course, Department of Agricultural Engineering, Federal University of Ceará, Fortaleza, 2016.

Lima Neto, I.E. 2019. Impact of artificial destratification on water availability of reservoirs in the Brazilian semiarid. Annals of the Brazilian Academy of Sciences. 91, 3.

Lima Neto, I.E., Wiegand, M.C., Araújo, J.C., 2011. Redistribution des sédiments due à un réseau dense de réservoirs dans un grand bassin versant semi-aride du Brésil. Hydrol. Sci. J. 56, 319-333. https://doi.org/10.1080/02626667.2011.553616

Lira, C.C.S., Medeiros, P.H.A., Neto, I.E.L., 2020. Modelling the impact of sediment management on the trophic state of a tropical reservoir with high water storage variations. An. Acad. Bras. Cienc. 92, 1-18. https://doi.org/10.1590/0001-3765202020181169

Loh, P.S., Molot, L.A., Nürnberg, G.K., Watson, S.B., Ginn, B., 2013. Evaluating relationships between sediment chemistry and anoxic phosphorus and iron release across three different water bodies. Inl. Waters 3, 105118. https://doi.org/10.5268/IW-3.1.533

Lopes, F.B., de Andrade, E.M., Meireles, A.C.M., Becker, H., Batista, A.A., 2014. Assessment of the water quality in a large reservoir in semiarid region of Brazil. Rev. Bras. Eng. Agric. e Ambient. 18, 437-445. https://doi.org/10.1590/S1415-43662014000400012

Mamede, G.L., Guentner, A., Medeiros, P.H.A., Araújo, J.C. De, Bronstert, A., 2018. Modeling the Effect of Multiple Reservoirs on Water and Sediment Dynamics in a Semiarid Catchment in Brazil 23, 1-13. https://doi.org/10.1061/(ASCE)HE.1943-5584.0001701.

Marques, L.O.D.A., Taffarello, D., Calijuri, M.D.C., Mendiondo, E.M., Ferreira, M. de S., Cunha, D.G.F., 2019. Phosphorus and thermotolerant coliforms' loads in brazilian watersheds with limited data: Considerations on the integrated analysis of water quality and quantity. Rev. Bras. Recur. Hidricos 24, 1-13. https://doi.org/10.1590/2318-0331.241920170137

Martins, E., Filho, F., Porto, M., 2006. O Processo de Mistura em Reservatórios do Semi-Árido e sua Implicação na Qualidade da Água. Rev. Bras. Recur. Hídricos 11, 109-119. https://doi.org/10.21168/rbrh.v11n4.p109119

Matias, N., Johnes, P.J., 2012. Catchment Phosphorous Losses: An Export Coefficient Modelling Approach with Scenario Analysis for Water Management 1041-1064. https://doi.org/10.1007/s11269-011-9946-3

Matisoff, G., Kaltenberg, E.M., Steely, R.L., Hummel, S.K., Seo, J., Gibbons, K.J., Bridgeman, T.B., Seo, Y., Behbahani, M., James, W.F., Johnson, L.T., Doan, P., Dittrich, M., Evans, M.A., Chaffin, J.D., 2016. Internal loading of phosphorus in western Lake Erie. J. Great Lakes Res. 42, 775-788. https://doi.org/10.1016/j.jglr.2016.04.004

Medeiros, L. C., Mattos, A., Lürling, M., Becker, V., 2015. Is the future blue-green or brown? The effects of extreme events on phytoplankton dynamics in a semi-arid man-made lake. Aquat. Ecol. 49, $293-307$. https://doi.org/10.1007/s10452-015-9524-5

Mesquita, J.B. de F., Lima Neto, I.E., Raabe, A., de Araújo, J.C., 2020. The influence of hydroclimatic conditions and water quality on evaporation rates of a tropical lake. J. Hydrol. 590, 125456. https://doi.org/10.1016/j.jhydrol.2020.125456

Molina-Navarro, E., Trolle, D., Martínez-Pérez, S., Sastre-Merlín, A., Jeppesen, E., 2014. Hydrological and water 
quality impact assessment of a Mediterranean limno-reservoir under climate change and land use management scenarios. J. Hydrol. 509, 354-366. https://doi.org/10.1016/j.jhydrol.2013.11.053

Moriasi, D.N., Arnold, J.G., Van Liew, M.W., Bingner, R.L., Harmel, R.D., Veith, T.L., 2007. Model evaluation guidelines for systematic quantification of accuracy in watershed simulations. Transactions Of The Asabe, 50, 885-900. https://doi.org/10.13031/2013.23153.

Moss, B., 2011. Allied attack: climate change and eutrophication. Inl. Waters 1, 101-105. https://doi.org/10.5268/iw-1.2.359

Moura, D.S., Lima Neto, I.E., Clemente, A., Oliveira, S., Pestana, C.J., Aparecida de Melo, M., Capelo-Neto, J., 2020. Modeling phosphorus exchange between bottom sediment and water in tropical semiarid reservoirs. Chemosphere 246. https://doi.org/10.1016/j.chemosphere.2019.125686

Nikolai, S.J., Dzialowski, A.R., 2014. Effects of internal phosphorus loading on nutrient limitation in a eutrophic reservoir. Limnologica 49, 33-41. https://doi.org/10.1016/j.limno.2014.08.005

North, R.L., Johansson, J., Vandergucht, D.M., Doig, L.E., Liber, K., Lindenschmidt, K.E., Baulch, H., Hudson, J.J., 2015. Evidence for internal phosphorus loading in a large prairie reservoir (Lake Diefenbaker, Saskatchewan). J. Great Lakes Res. 41, 91-99. https://doi.org/10.1016/j.jglr.2015.07.003

Nürnberg, G.K. 1984. The prediction of internal phosphorus load in lakes with anoxic hypolimnia. Limnol. Oceanogr. 29, 1. 111-124.

Nürnberg, G.K., 2009. Assessing internal phosphorus load - Problems to be solved. Lake Reserv. Manag. 25, 419 432. https://doi.org/10.1080/00357520903458848

Nürnberg, G.K., LaZerte, B.D., Loh, P.S., Molot, L.A., 2013. Quantification of internal phosphorus load in large, partially polymictic and mesotrophic Lake Simcoe, Ontario. J. Great Lakes Res. 39, 271-279. https://doi.org/10.1016/j.jglr.2013.03.017

Nürnberg, G.K., Tarvainen, M., Ventelä, A.M., Sarvala, J., 2012. Internal phosphorus load estimation during biomanipulation in a large polymictic and mesotrophic lake. Inl. Waters 2, 147-162. https://doi.org/10.5268/IW-2.3.469

Oliveira, K.F., Lacerda, L.D., Peres, T.F., Bezerra, M.F., da Silva Dias, F.J., 2015. Emission factor and balance of mercury in fish farms in an artificial reservoir in NE Brazil. Environ. Sci. Pollut. Res. 22, 18278-18287. https://doi.org/10.1007/s11356-015-5102-6

Orihel, D.M., Schindler, D.W., Ballard, N.C., Graham, M.D., O'Connell, D.W., Wilson, L.R., Vinebrooke, R.D., 2015. The "nutrient pump:" Iron-poor sediments fuel low nitrogen-to-phosphorus ratios and cyanobacterial blooms in polymictic lakes. Limnol. Oceanogr. 60, 856-871. https://doi.org/10.1002/lno.10076

Orihel, D. M., Baulch, H. M., Casson, N. J., North, R. L., Parsons, C. T., Seckar, D. C. M., Venkiteswaran, J. J., 2017. Internal phosphorus loading in Canadian fresh waters: a critical review and data analysis. Canadian Journal Of Fisheries And Aquatic Sciences. 74. 12. 2005-2029. http://dx.doi.org/10.1139/cjfas-2016-0500.

Pacheco, C.H.A., Lima Neto, I.E., 2017. Effect of artificial circulation on the removal kinetics of cyanobacteria in a hypereutrophic shallow lake. J. Environ. Eng. 143 (12). https://doi.org/10.1061/(ASCE)EE.19437870.0001289.

Paula Filho, F.J., Sampaio, A.D. de S., Menezes, J.M.C., Costa, C.T.F. da, Santiago, M.O., 2019. Land uses, Nitrogen and Phosphorus estimated fluxes in a Brazilian semi-arid watershed. J. Arid Environ. 163, 41-49. https://doi.org/10.1016/j.jaridenv.2019.01.001 
Pilotti, M., Simoncelli, S., Valerio, G., 2014. A simple approach to the evaluation of the actual water renewal time of natural stratified lakes. Water Resources Research. 50, 2830-2849. https://doi.org/10.1002/2013wr014471

Qin, L.; Zeng, Q.; Zhang, W.; Li, X.; Steinman, Alan D.; Du, X. 2016. Estimating internal P loading in a deep water reservoir of northern China using three different methods. Environmental Science and Pollution Research, 23 (18), 18512-18523. http://dx.doi.org/10.1007/s11356-016-7035-0.

Rattan, K.J., Corriveau, J.C., Brua, R.B., Culp, J.M., Yates, A.G., Chambers, P.A., 2017. Quantifying seasonal variation in total phosphorus and nitrogen from prairie streams in the Red River Basin, Manitoba Canada. Sci. Total Environ. 575, 649-659. https://doi.org/10.1016/j.scitotenv.2016.09.073

Salas, H., Martino, P. A., 1991. Simplified phosphorus trophic state model for warm-water tropical lakes. Water Research, 25, 341-350. https://doi.org/10.1016/0043-1354(91)90015-I

Santos, J.A. dos, de Oliveira, K.F., da Silva Araújo, I.C., Avelino, I.I.F., de Sousa Cajuí, K.N., de Lacerda, L.D., Marins, R.V., 2016. Phosphorus partitioning in sediments from a tropical reservoir during a strong period of drought. Environ. Sci. Pollut. Res. 23, 24237-24247. https://doi.org/10.1007/s11356-016-7629-6

Schauser, I., Chorus, I., 2009. Water and phosphorus mass balance of Lake Tegel and Schlachtensee - A modelling approach. Water Res. 43, 1788-1800. https://doi.org/10.1016/j.watres.2009.01.007

Schindler, D.W., 2006. Recent advances in the understanding and management of eutrophication. Limnol. Oceanogr. 51, 356-363.

Seitz, C., Scordo, F., Vitale, A.J., Vélez, M.I., Perillo, G.M.E., 2020. The effects of extreme drought events on the morphometry of shallow lakes: Implications for sediment resuspension and littoral and pelagic zone distribution. J. South Am. Earth Sci. 103, 102743. https://doi.org/10.1016/j.jsames.2020.102743

Shimoda, Y., Arhonditsis, G.B., 2015. Integrating hierarchical Bayes with phosphorus loading modelling. Ecol. Inform. 29, 77-91. https://doi.org/10.1016/j.ecoinf.2015.07.005

Song, K., Adams, C.J., Burgin, A.J., 2017. Relative importance of external and internal phosphorus loadings on affecting lake water quality in agricultural landscapes. Ecol. Eng. 108, 482-488. https://doi.org/10.1016/j.ecoleng.2017.06.008

Søndergaard, M., Jensen, J.P., Jeppesen, E., 2003. Role of sediment and internal loading of phosphorus in shallow lakes. Hydrobiologia 506-509: 135-145.

Souza Filho, F. A, Martins, E. S. P. R., Porto, M. F. A., 2006. The Mixing Process in Semi-Arid Reservoirs and its Implication in Water Quality. Rev Bras Recur Hídricos 11(4): 109-119.

Sperling, M. V. (2007). Wastewater Cahracteristcs, Treatment and Disposal, Iwa Publishing, New York, 292 pp.

Toné, A. Lima Neto, I. 2019. Simplified modeling of total phosphorus in Brazilian lakes and reservoirs. Rev. DAE, $221,142-156$.

Tsakiris, G., Alexakis, D., 2015. Water quality models : An overview 33-46.

Vollenweider, R. A., 1968. Water management research. Scientific fundamentals of the eutrophication of lakes and flowing waters with particular reference to nitrogen and phosphorus as factors in eutrophication. Organization for Economic Co-operation and De. Limnology and Oceanography, 15, 169-170. https://doi.org/10.4319/lo.1970.15.1.0169

Vollenweider, R. A., 1976. Advances in defining critical loading levels for phosphorus in lake eutrophication. Memorie Dell'istituto Italiano di Idrobiologia, 33, 53-83. 
von Schiller, D., Bernal, S., Dahm, C.N., Martí, E., 2017. Nutrient and Organic Matter Dynamics in Intermittent Rivers and Ephemeral Streams, in: Intermittent Rivers and Ephemeral Streams: Ecology and Management. Elsevier Inc., pp. 135-160. https://doi.org/10.1016/B978-0-12-803835-2.00006-1

Wiegand, M.C., do Nascimento, A.T.P., Costa, A.C., Lima Neto, I.E., 2021. Trophic state changes of semi-arid reservoirs as a function of the hydro-climatic variability. J. Arid Environ. 184. https://doi.org/10.1016/j.jaridenv.2020.104321

Zhang, Z., Chen, X., Xu, C.Y., Hong, Y., Hardy, J., Sun, Z., 2015. Examining the influence of river-lake interaction on the drought and water resources in the Poyang Lake basin. J. Hydrol. 522, 510-521. https://doi.org/10.1016/j.jhydrol.2015.01.008 


\section{Figures}

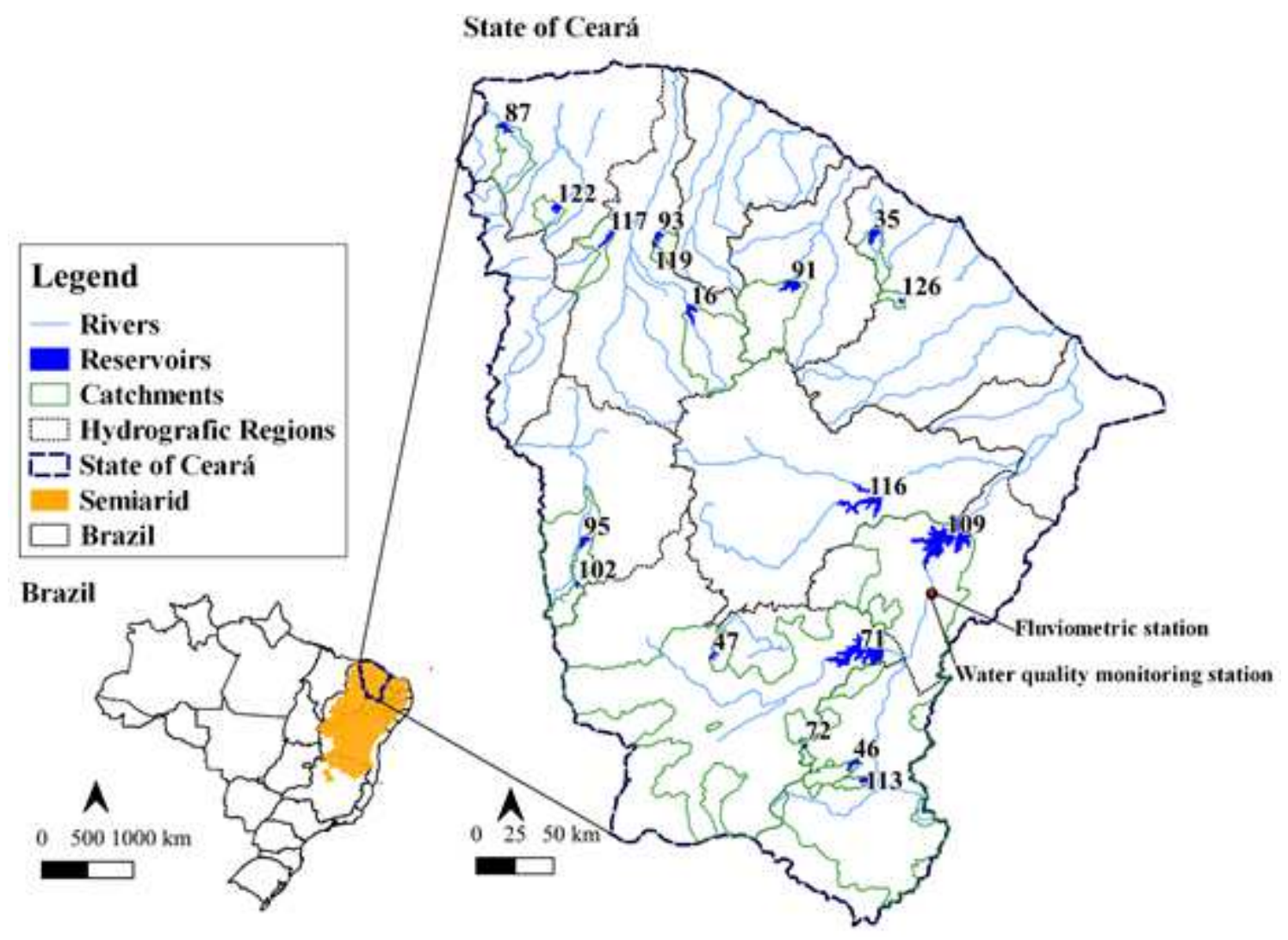

Figure 1

Location of the eighteen studied sites in the State of Ceará - Brazil, whose description is presented in Table 1. Note: The designations employed and the presentation of the material on this map do not imply the expression of any opinion whatsoever on the part of Research Square concerning the legal status of any country, territory, city or area or of its authorities, or concerning the delimitation of its frontiers or boundaries. This map has been provided by the authors.

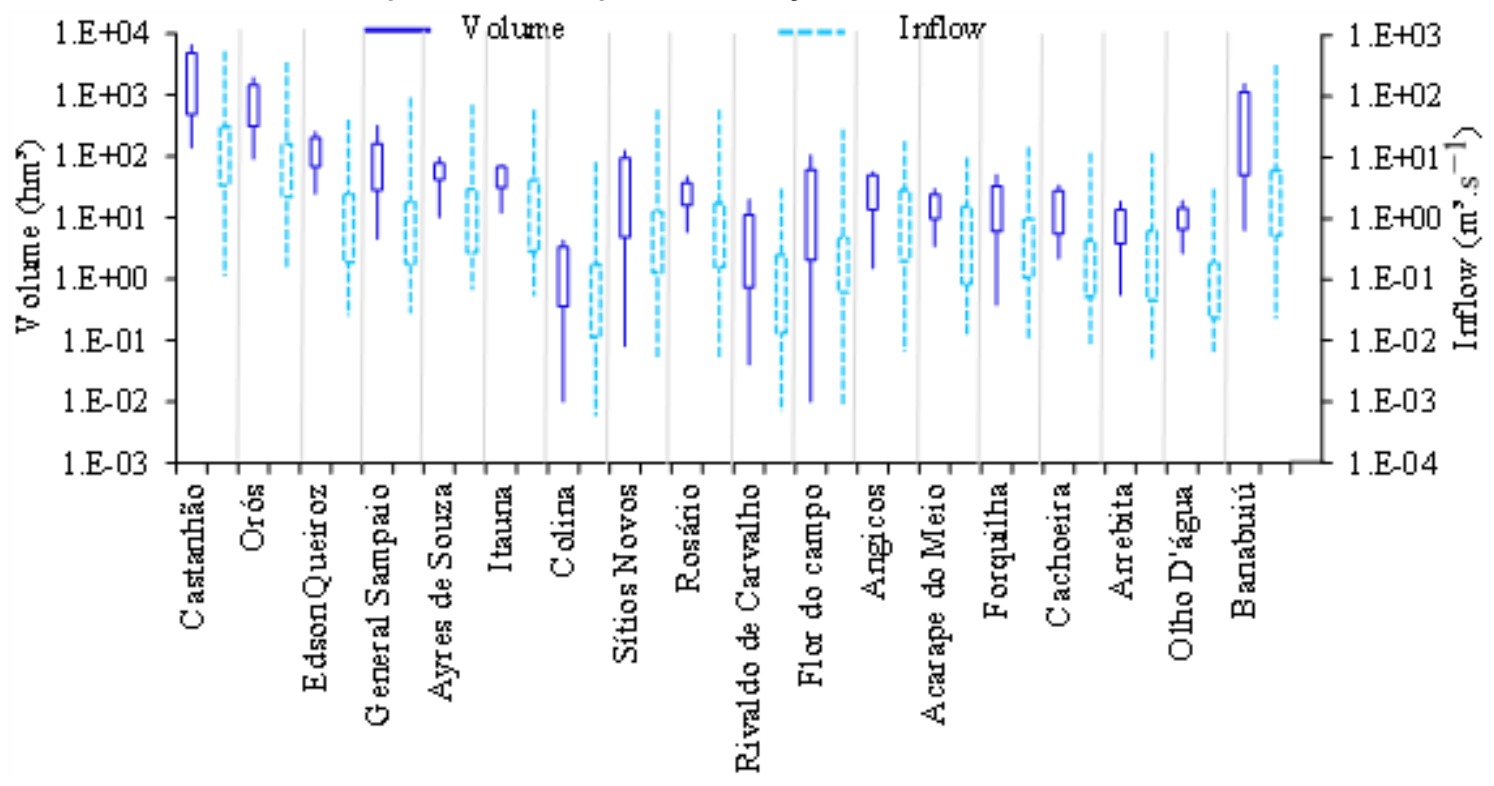


Figure 2

Main hydrologic variables of each reservoir for the studied period

(a)

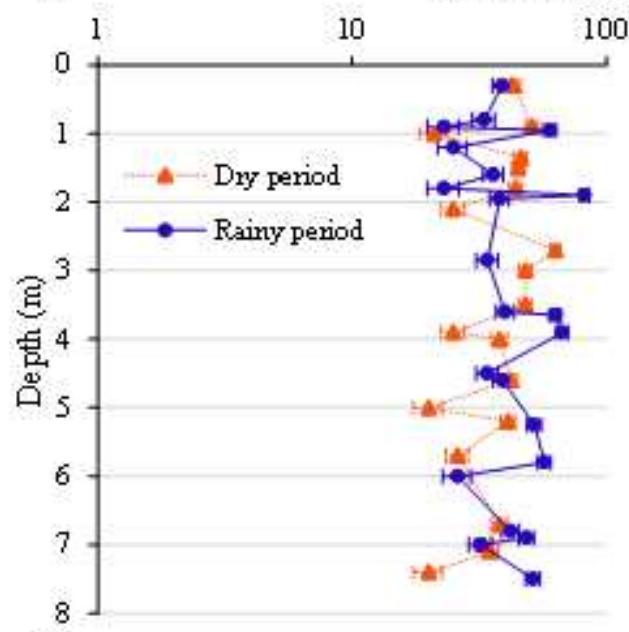

(c)

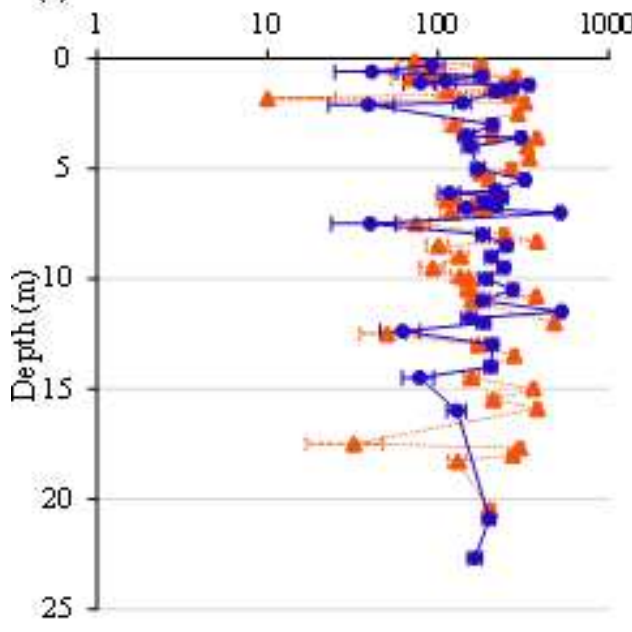
Average TP concentration $\left(\mu . \mathrm{L}^{-1}\right)$

(b)

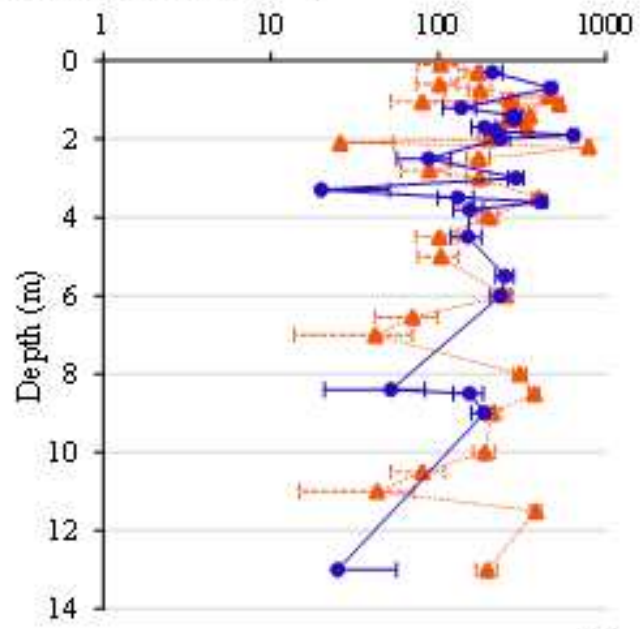

(d)

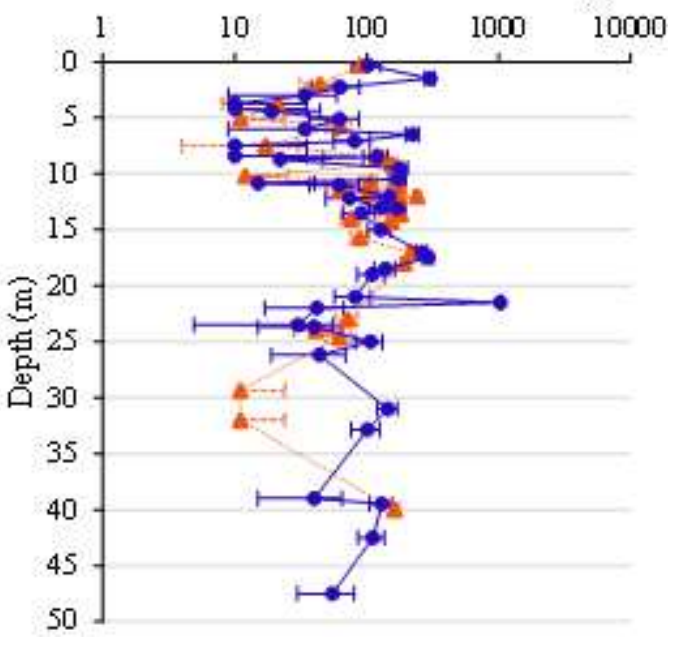

\section{Figure 3}

TP concentration in the water column for the sampling point near the dam of the reservoir (a) Itaúna, (b) Sítios Novos, (c) Acarape do Meio e (d) Castanhão. Averages from 2008 to 2019 and standard errors (bars) are presented 


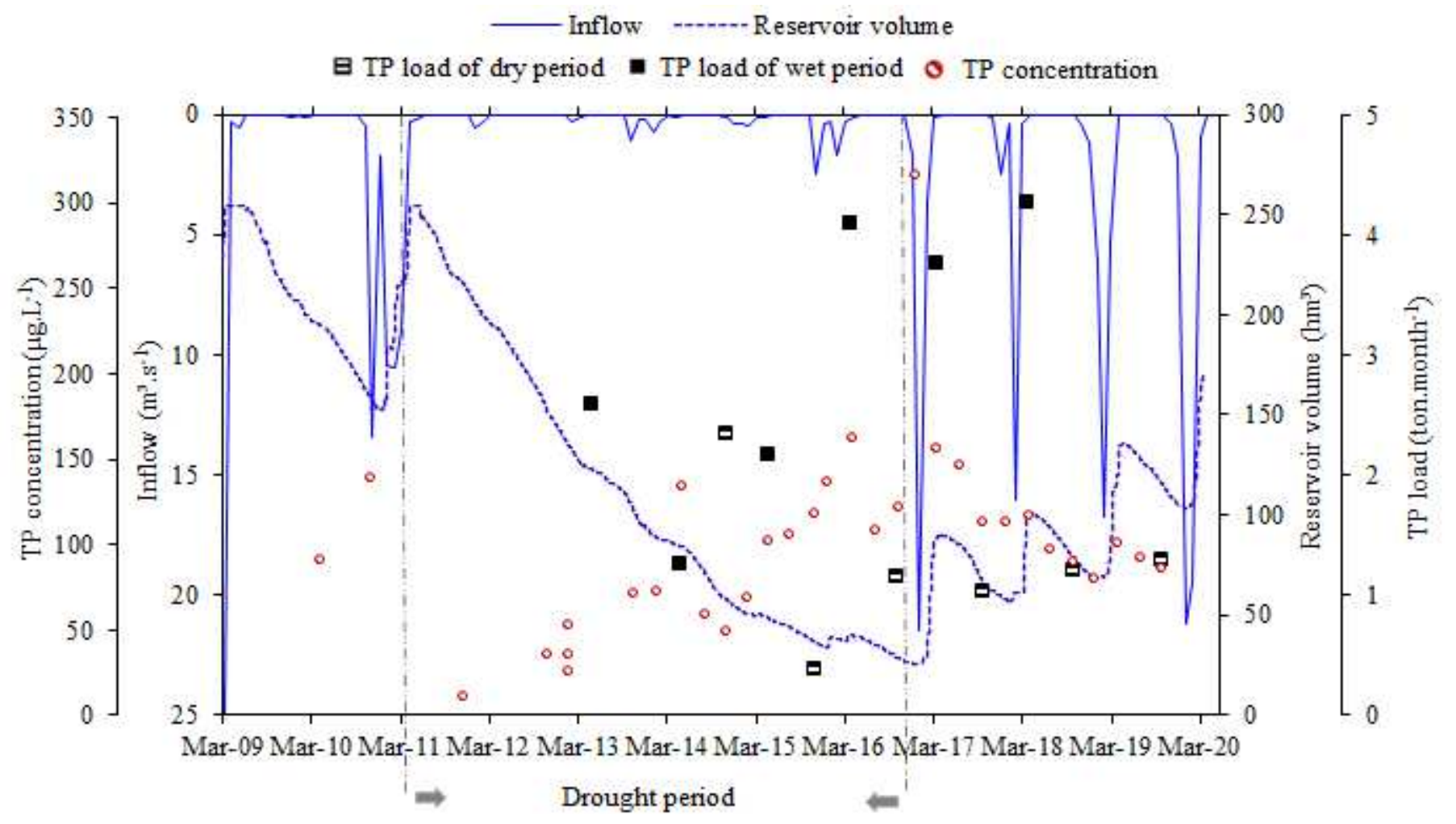

Figure 4

Time series of volume, inflow, TP concentration and wet/dry period loads for the reservoir Edson Queiroz 


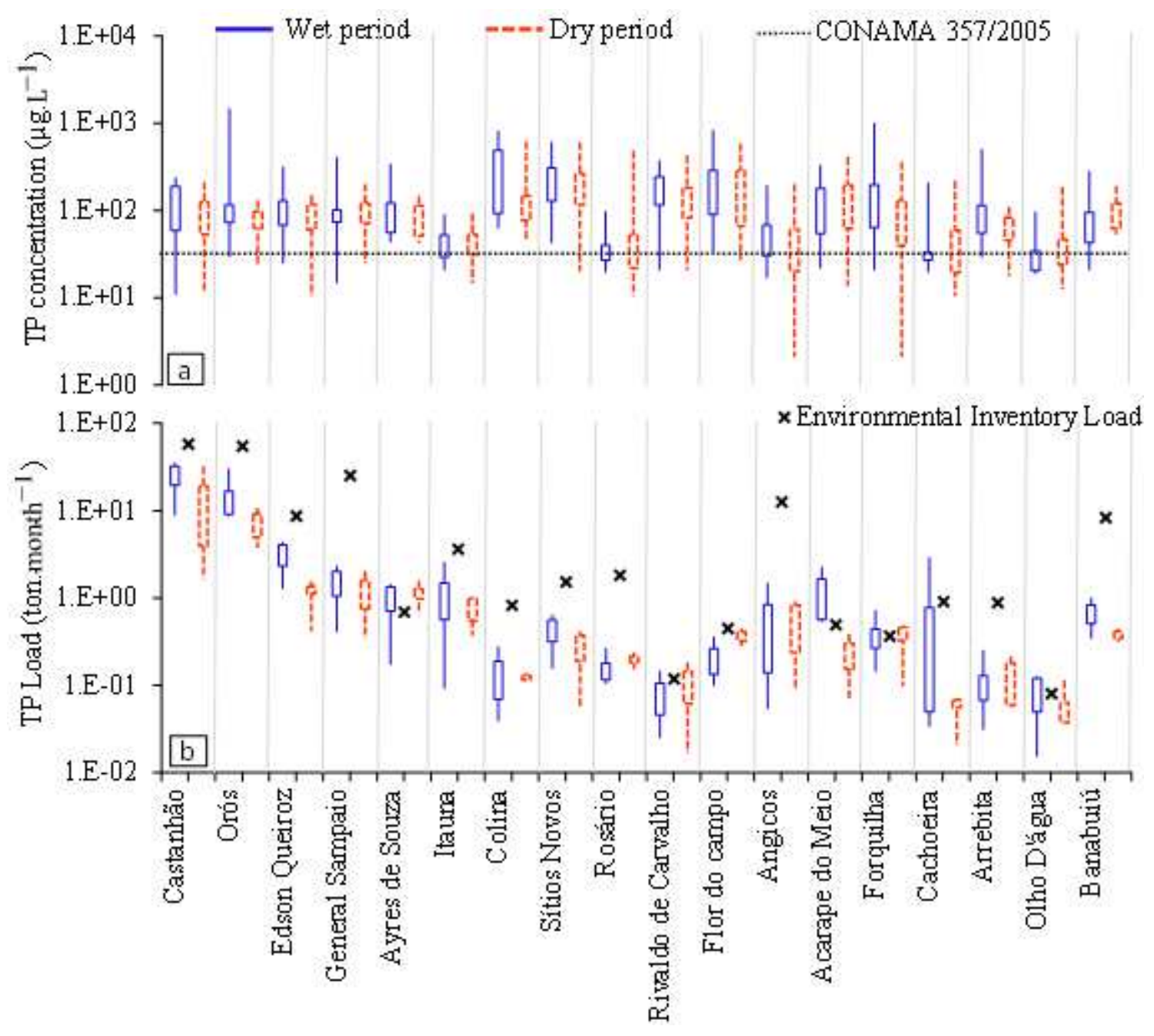

Figure 5

Epilimnion TP concentration (a) and modeled TP loads (b) for the dry and wet periods

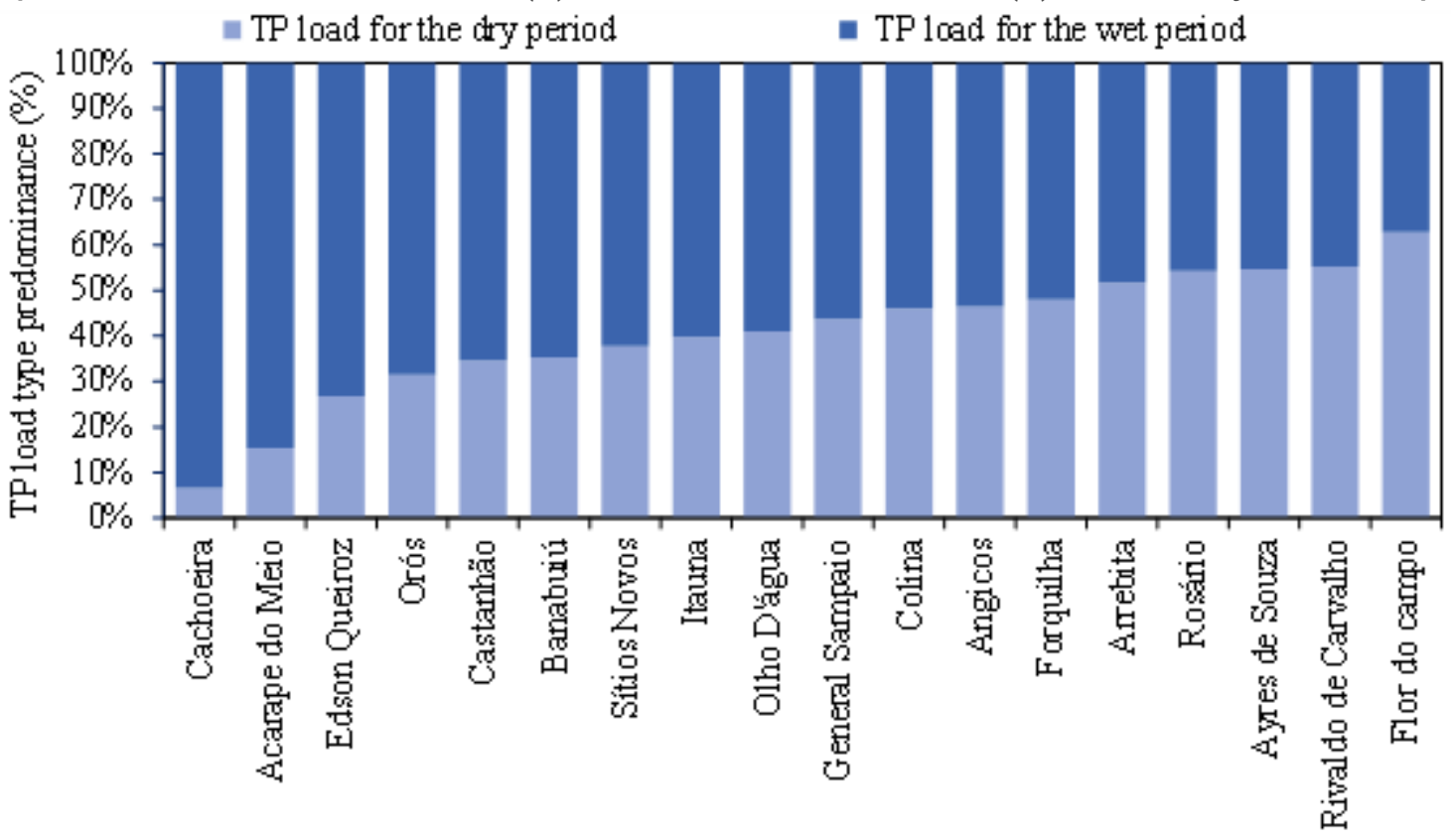

Figure 6 
Assessment of the representativeness of the loads produced in the wet and dry seasons in the annual TP load
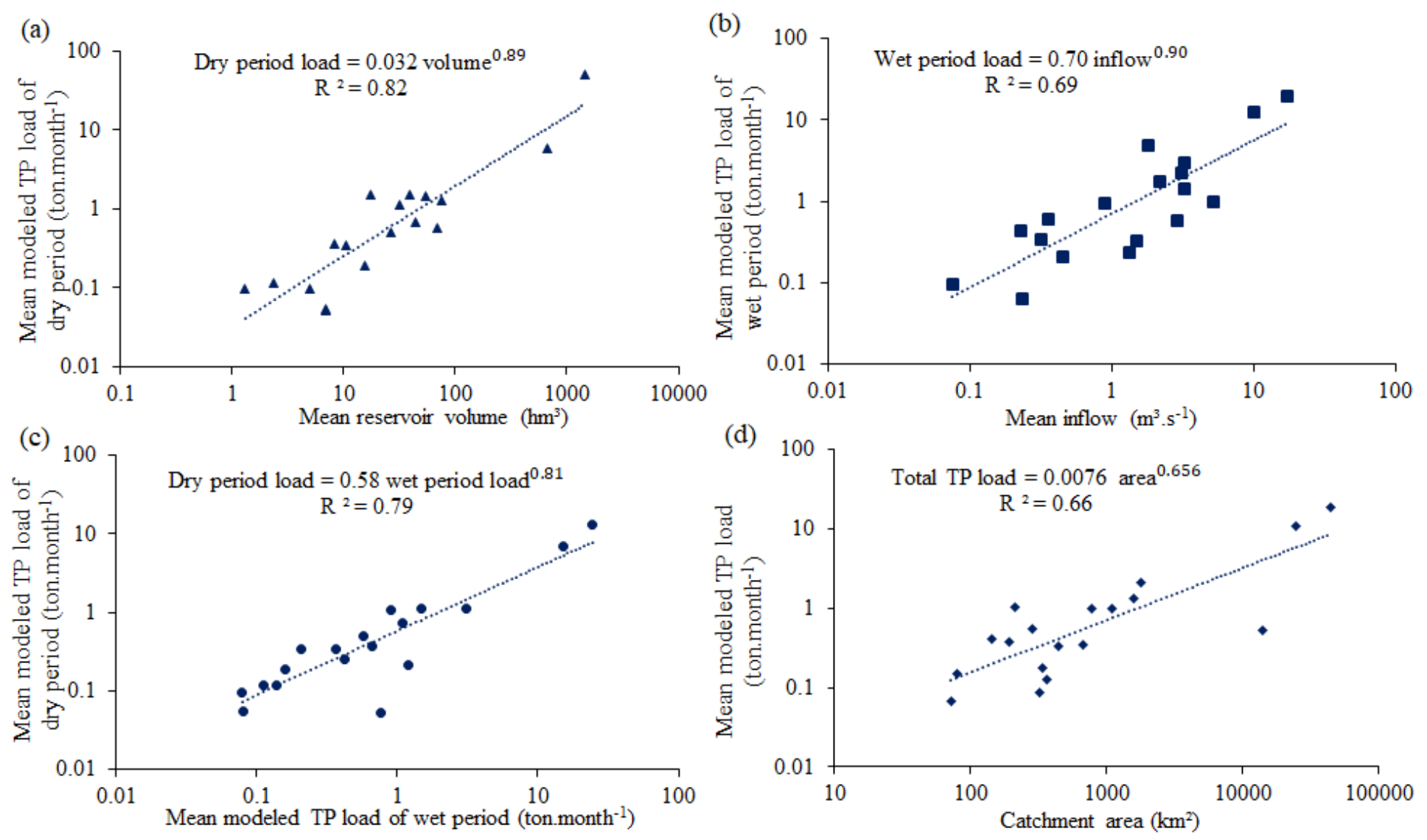

\section{Figure 7}

Proposed models for the (a) TP load of dry period as function of the volume, (b) TP load of wet period as function of the inflow, (c) TP load of dry period as function of the TP load of wet period and (d) Total TP load as function of the catchment area

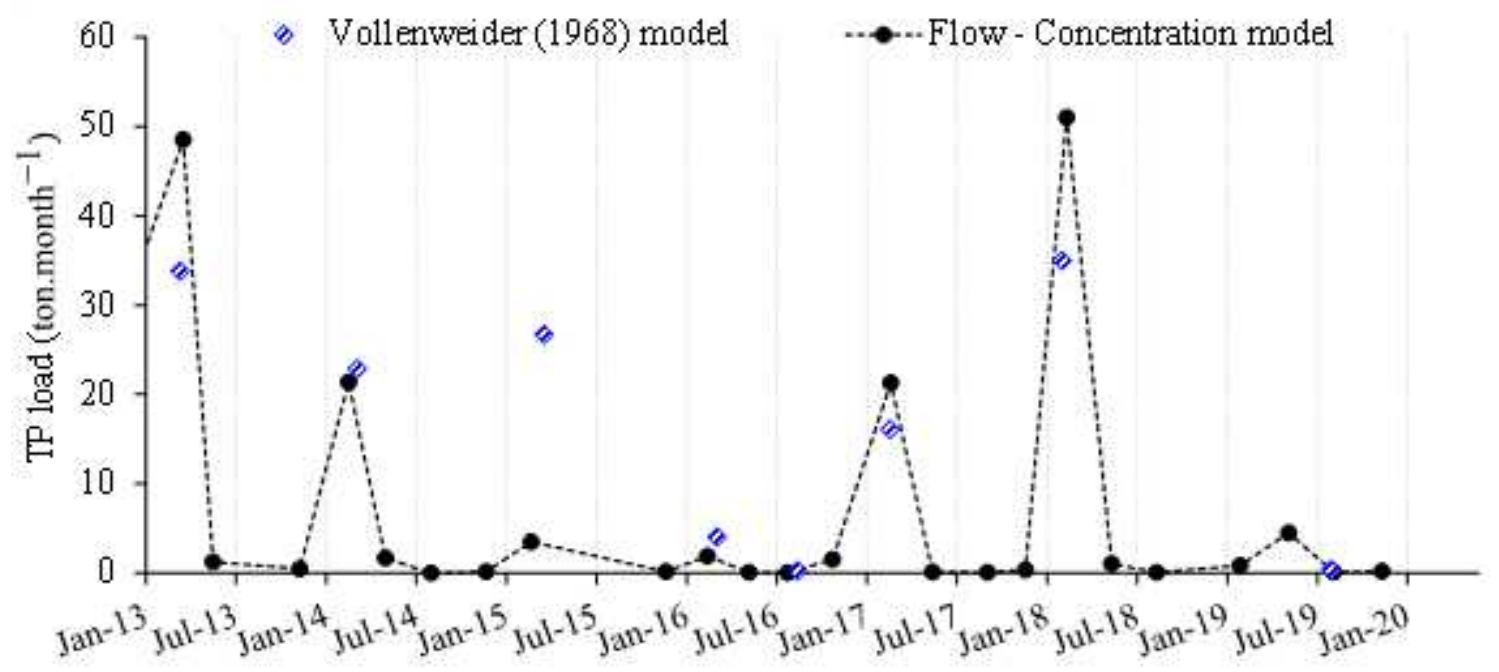

\section{Figure 8}


Comparison of the total TP load input to the Castanhão reservoir by using two different approaches 